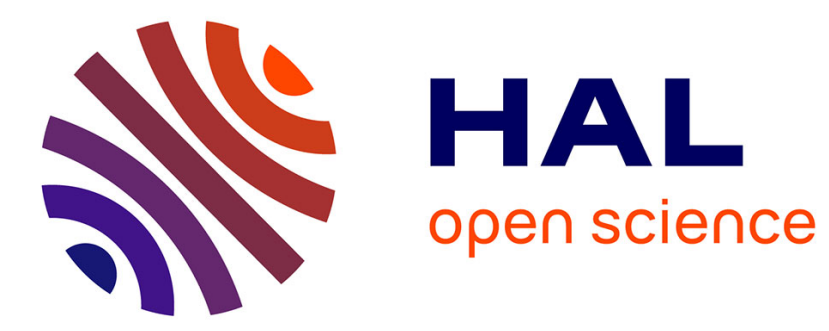

\title{
Geomorphic and vegetation changes in a meandering dryland river regulated by a large dam, Sauce Grande River, Argentina
}

\author{
Ana Casado, Jean-Luc Peiry, Alicia M. Campo
}

\section{To cite this version:}

Ana Casado, Jean-Luc Peiry, Alicia M. Campo. Geomorphic and vegetation changes in a meandering dryland river regulated by a large dam, Sauce Grande River, Argentina. Geomorphology, 2016, 10.1016/j.geomorph.2016.05.036 . hal-01332432

\section{HAL Id: hal-01332432 \\ https://hal.science/hal-01332432}

Submitted on 16 Jun 2016

HAL is a multi-disciplinary open access archive for the deposit and dissemination of scientific research documents, whether they are published or not. The documents may come from teaching and research institutions in France or abroad, or from public or private research centers.
L'archive ouverte pluridisciplinaire HAL, est destinée au dépôt et à la diffusion de documents scientifiques de niveau recherche, publiés ou non, émanant des établissements d'enseignement et de recherche français ou étrangers, des laboratoires publics ou privés. 
1 Geomorphic and vegetation changes in a meandering dryland river regulated by a large 2 dam, Sauce Grande River, Argentina

*Corresponding autor. Departamento de Geografía y Turismo, Universidad Nacional del

\section{Abstract}

This paper investigates post-dam geomorphic and vegetation changes in the Sauce Grande

River, a meandering dryland river impounded by a large water-conservation dam. As the dam impounds a river section with scarce influence of tributaries, sources for fresh water and sediment downstream are limited. Changes were inspected based on (i) analysis of historical photographs/imagery spanning pre- (1961) and post-dam $(1981,2004)$ channel conditions for two river segments located above and below the dam, and (ii) field survey of present channel conditions for a set of eight reference reaches along the river segments. Whilst the unregulated river exhibited active lateral migration with consequent adjustments of the channel shape and size, the river section below the dam was characterized by (i) marked planform stability (93 to 97\%), and by (ii) vegetation encroachment leading to alternating yet localized contraction of the channel width (up to $30 \%$ ). The present river displays a moribund, stable channel where (i) redistribution of sediment along the river course no longer occurs and (ii) channel forms constitute a remnant of a fluvial environment created before closing the

31 dam, under conditions of higher energy. In addition to providing new information on the complex geomorphic response of dryland rivers to impoundment, this paper represents the 
very first geomorphic assessment of the regulated Sauce Grande and therefore provides an important platform to underpin further research assessing the geomorphic state of this highly regulated dryland river.

Keywords: flow regulation; geomorphic changes; vegetation changes; dryland rivers; Sauce Grande River; Paso de las Piedras Dam

\section{Introduction}

Drylands - which include dry-subhumid, semiarid, arid, and hyperarid regions - cover $40 \%$ of the Earth's surface and contain almost $40 \%$ of the global population (UNEM, 2011).

Population growth and changing living standards force increased water allocation for urban, agricultural and industrial use (Young and Kingsford, 2006; Schmandt et al., 2013). As a result, water resources in drylands tend to be heavily exploited through dams, weirs, canals, and other structures (Davies et al., 1994). Although most dams in drylands are multipurpose dams, with hydropower and flood control as common primary functions, many of them operate as water-conservation structures to support irrigation and/or drinking water supply. Water- conservation dams maintain the reservoir as full as possible and impound the entire runoff volume in periods of reservoir filling (Petts, 1984). Thus, the disparity between natural and regulated flow regimes may be particularly striking in drylands (Walker et al., 1995).

One particular concern is that dryland fluvial processes (and therefore the fluvial response to impoundment) may be very different from those generally accepted in more humid regions (Tooth, 2000b, 2013; Nanson et al., 2002). Dryland rivers are characterized by extreme variability in flow and sediment transport (Davies et al., 1994; Bunn et al., 2006; Young and Kingsford, 2006). Long periods of little or no flow are interspersed with floods of high, sometimes extreme magnitude (Tooth and Nanson, 2000), short duration (Graf, 1988), and low predictability (Poff and Ward, 1989). Floods control erosion, transport, and deposition 
processes (Bull and Kirkby, 2002) and therefore constitute the major determinant of dryland channel shape and size (Tooth, 2000b). As morphogenetic floods exhibit highly skewed frequency (Tooth, 2000b), complete adjustment of dryland channel form to process is sometimes inhibited (Bull and Kirkby, 2002). Feedback mechanisms between channel form and process are rarely found in drylands (Tooth, 2000a), and therefore researchers have a tendency to presume that dryland rivers are in an unstable, nonequilibrium state (Tooth and Nanson, 2000).

The unstable character of natural dryland rivers challenges assessing the impacts of flow regulation on dryland channel forms. Notable advances on the complex response of dryland rivers to impoundment have been made in the United States and Australia, as well as in central Asia, South Africa, and South America in minor extent. For example, Friedman et al. (1998) found that regulated braided rivers in the American Great Plains tend to narrow owing to vegetation encroachment (such as has occurred in the Orange River, South Africa; Blanchon and Bravard, 2007), whereas meandering rivers tend to reduce their migration rates (e.g., the upper Missouri; Shields et al., 2000). In the American Southwest (e.g., Green River; Merritt and Cooper, 2000; Grams and Schmidt, 2002), the most common response to impoundment involved reduced channel capacity by aggradation and vegetation invasion of lateral deposits, such as has occurred in dryland rivers of Australia (e.g., Cudgegong River; Benn and Erskine, 1994), the Mediterranean Basin (e.g., Medjerda River in Tunisia; Zahar et al., 2008), and South America (e.g., Chubut River in Argentina; Kaless et al., 2008). The studies cited above, among many others, have certainly contributed to the understanding of form to process relationships in regulated dryland rivers. Yet most of the previous research has centred on locations where tributaries contribute water and sediment below the dam, and very few studies have investigated geomorphic adjustments in flood-driven, regulated dryland rivers where tributary influence below the dam is scarce. 
This paper examines geomorphic and vegetation adjustments in a meandering dryland river where (i) flow regulation is extreme and (ii) sources for flow and sediment below the dam are limited to erratic reservoir discharges and reworked local alluvium because the river flows without influence of tributaries. It aims to address two fundamental questions: (i) how do flood-driven, dryland channels adjust their morphology in highly regulated, low stream power settings with scarce influence of tributaries? and (ii) how does riparian vegetation interact with (and react to) altered river hydrology and morphology in dry, highly regulated fluvial settings? The study centres on the Sauce Grande River below the Paso de las Piedras Dam (central-eastern Argentina), where prior geomorphic assessment is limited to reconstructions of Quaternary fluvial processes at the broad scale of the river basin. Change in channel geometry (planform and cross section) and riparian vegetation structure are quantified simultaneously above and below the dam using a sequence of rectified aerial photographs and high-resolution imagery spanning pre- and post-dam channel conditions. Changes as a function of distance downstream from the dam are also examined.

\section{Materials and methods}

\subsection{Study site}

The Sauce Grande River collects its waters on the eastern slope of the Sierra de la Ventana Range and flows down into the Atlantic Ocean draining a basin area of $\sim 4600 \mathrm{~km}^{2}$ (Fig. 1). The climate in the majority of the river basin is dry-subhumid. Mean annual rainfall decreases from $800 \mathrm{~mm}$ in the uplands to $640 \mathrm{~mm}$ in the lowlands, and mean annual potential evapotranspiration is $1030 \mathrm{~mm}$ (Paoloni et al., 1972). Interannual rainfall variability is marked and linked primarily to alternating phases of ENSO (Scian, 2000), inducing episodes of drier- and wetter-than-normal climate (Campo et al., 2009; Bohn et al., 2011). Recurrence 
108 local water resources (Andrés et al., 2009).

109

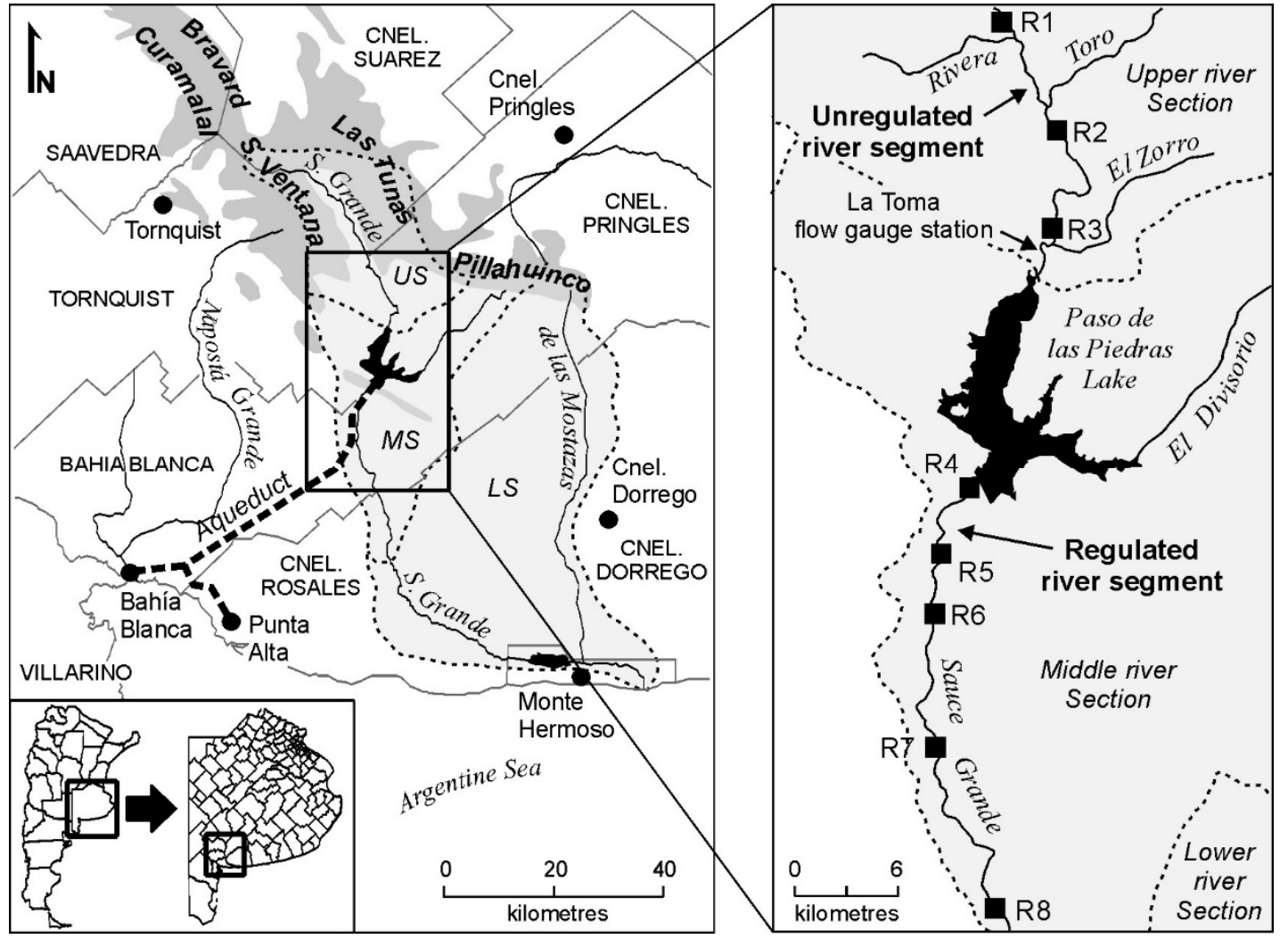

Fig. 1. Map of the Sauce Grande River basin showing main regional features (left) and the river segments selected for analysis (right). The location of reference river reaches $(\mathrm{R})$ along each river segment is also illustrated. US, MS and LS in the left map designate the upper, middle, and lower river sections, respectively.

\subsubsection{Hydrological context}

The natural river flow regime is perennial flashy (rainfed) and event-driven. Mean daily flow (1910-1947) is $3.4 \mathrm{~m}^{3} \mathrm{~s}^{-1}$, but floods may reach more than $1000 \mathrm{~m}^{3} \mathrm{~s}^{-1}$ in a few hours (Schefer, 2004). The Paso de las Piedras Dam (initiated in 1972 and completed in 1978) impounds the middle river section for water supply to the cities of Bahía Blanca and Punta Alta (Fig. 1). Its reservoir has a surface area of $36 \mathrm{~km}^{2}$ and a maximum storage capacity of $328 \mathrm{~m}^{3} 10^{-6}$ for 25 $\mathrm{m}$ depth (Schefer, 2004). Annual yield to meet water demand is $65 \mathrm{~m}^{3} 10^{-6}$; this is about $60 \%$ of the mean annual inflow volume $\left(107.2 \mathrm{~m}^{3} 10^{-6}\right)$. The remaining volume is conserved within 
the reservoir to assure water supply in periods of drought; flow release downstream occurs

123 only in periods of full storage. Water is conducted either through the bottom gate (controlled

124 flow releases) or through the overflow spill weir (uncontrolled release).

125 Figure 2 illustrates monthly runoff volumes at La Toma (Fig. 1) and monthly volumes of

126 reservoir discharge as a surrogate of flow magnitude upstream and downstream from the dam.

127 Gauged and estimated reservoir discharges indicate that the reservoir has absorbed the full

128 range of inflow volumes over 19 years of record (48\%). In years recording reservoir

129 discharges, annual runoff volumes were reduced by $54 \%$, annual maxima were reduced by

$13042 \%$, and annual minima were reduced by $86 \%$. The reservoir history registers only two

131 episodes of overflow spills (1984 and 2002), during which the flood wave was attenuated by

13231 and $34 \%$, respectively. In the absence of flow release, downstream flow averages $0.26 \mathrm{~m}^{3} \mathrm{~s}^{-}$

$133{ }^{1}$ and originates from reservoir seepage below the dam structure. Except for some ephemeral

134 tributaries, the Sauce Grande River receives no permanent flow inputs until its confluence

135 with de las Mostazas Creek (lower river section; Fig. 1) about 110 river km downstream from

136 the dam closure.

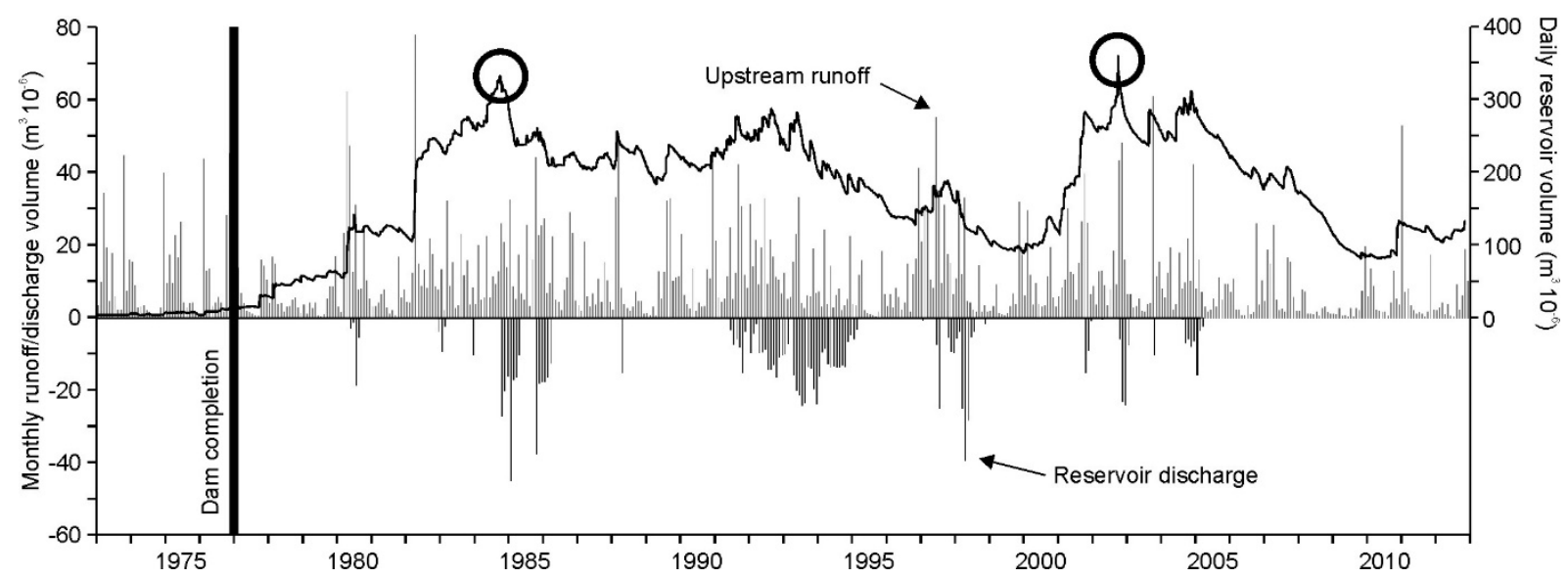

138 Fig. 2. Monthly runoff volume upstream from the dam and monthly volumes of reservoir

139 discharge over the period 1973-2012. Upstream runoff volumes were estimated from rainfall

140 using the GR2M model (Makhlouf and Michel, 1994). Monthly volumes of reservoir

141 discharge over the period 1973-1988 were calculated by solving the reservoir water balance 
142 equation (missing data). Daily reservoir volumes were illustrated to provide an idea of the

143 hydrological magnitude of the dam relative to that of the river. Circles indicate episodes of

144 overflow spills.

\section{2.1.2. Geomorphic context}

146 In its upper-middle course, the Sauce Grande River exhibits clear meandering patterns, low

147 longitudinal gradient (0.002, in average), and pool-riffle bed morphology. It flows on the

148 bottom of a broad and deeply incised valley (Rabassa, 1982) excavated on Pliocene-

149 Pleistocene loess deposits (Quattrocchio et al., 1993). Three terrace remnants along the valley

150 (T0 to T2; Fig. 3) give evidence of at least three superimposed sequences of valley incision

151 and compound fill, including gravitational, aeolian, and ephemeral fluvial deposits (Zavala

152 and Quattrocchio, 2001; Quattrocchio et al., 2008).

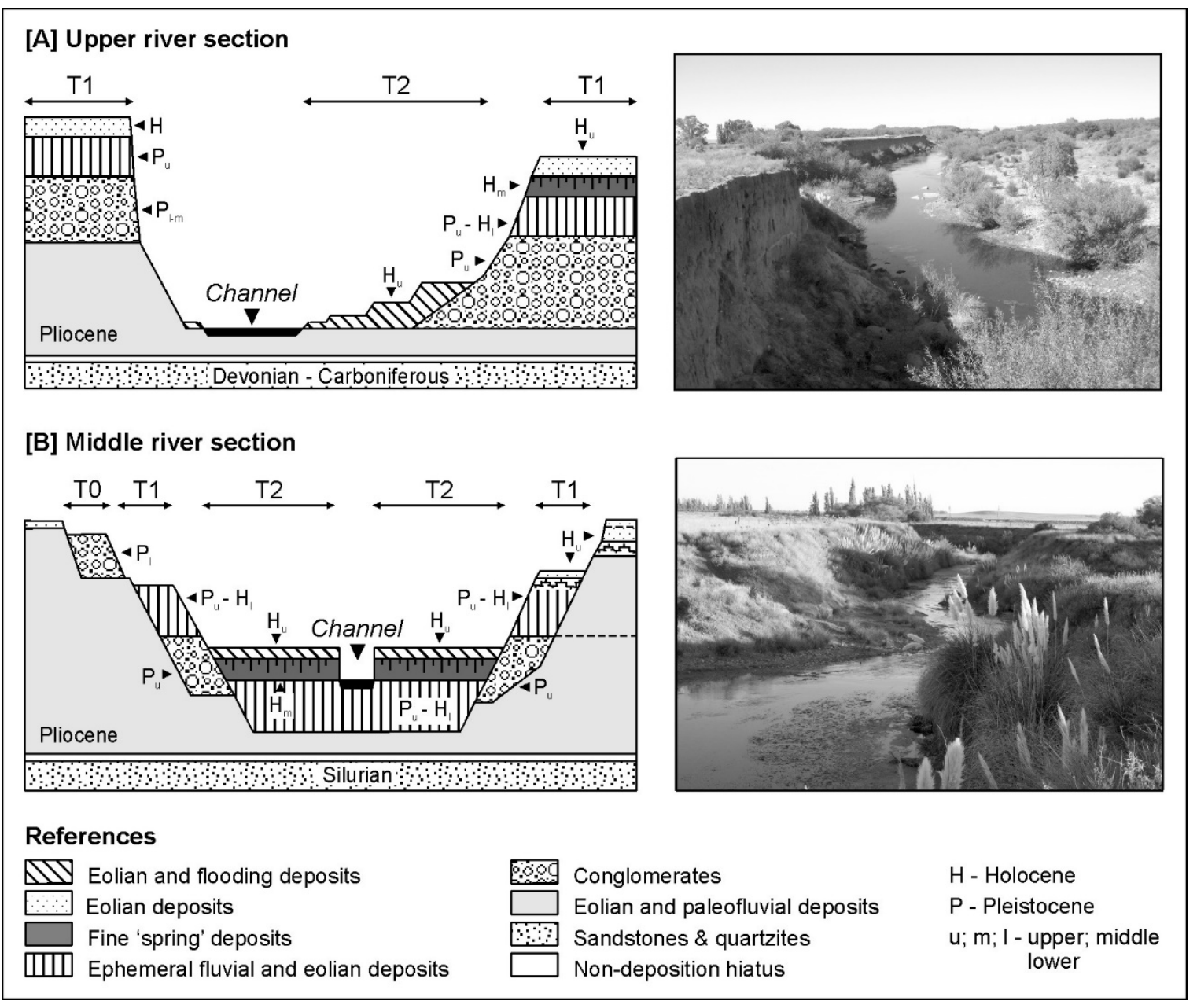

154 Fig. 3. Schematic cross sections of the Sauce Grande River showing typical geomorphic and 
geologic characteristics within the upper and middle river sections. Geologic features were modified from Borromei (1991), Zavala and Quattrocchio (2001), and Quattrocchio et al. (2008). Not to scale.

158 Downstream variations in channel forms and size are apparent (Fig. 3) and conceivably linked

159 to the attenuation of floods and flow transmission losses characteristic of dryland

160 environments (Tooth, 2000a). In the upper section, the river channel is wide, shallow, and

161 develops on the bottom of the incised valley. Migration of the meanders and point bar

162 building outward led to formation of small terrace steps that have changed the original

163 configuration of the valley bottom. In the middle river section, the valley broadens markedly,

164 the terraces lose altitude, and the degree of confinement decreases. The river flows through a

165 narrow, deep, and tortuous channel that constitutes a remnant of an ancient braided

166 morphology (Borromei, 1991). Former braids were covered by aeolian deposits, and the

167 present floodplain constitutes an abandoned portion of the original braided channel.

\subsection{Scales of analysis}

170 This paper quantifies post-dam geomorphic and vegetation changes across multiple scales

171 (Fig. 4). Changes with time were inspected using a chronological sequence of historical aerial

172 photographs $(1961,1981)$ and high-resolution imagery (Ikonos, 2004) defining two

173 comparative periods. The first period (1961-1981) spans a pre-disturbance phase,

174 characterized by unregulated flow conditions, and a phase of early disturbance linked to dam

175 completion in 1978 and initial filling of the reservoir (Fig. 2). The second period (1981-2004)

176 spans the post-disturbance phase where the dam controls the magnitude, frequency, duration,

177 and variability of downstream flows. Changes from unregulated to regulated river conditions

178 for a given time step were inspected by contrasting two river segments located above and

179 below the dam ( 26- and 41-km length, respectively). In addition, field-based descriptions of 
181 length located above (3 reaches) and below (5 reaches) the dam (Fig. 1).

182

183 Fig. 4. Spatial and temporal scales used in geomorphic and vegetation analysis. Quantification of change within the regulated river segment $\left(\mathrm{RS}_{\mathrm{D}}\right)$ is performed with time $\left(\mathrm{RS}_{\mathrm{D}} \rightarrow \mathrm{RS}_{\mathrm{D}}\right.$ ") and with respect to the unregulated river segment upstream $\left(\mathrm{RS}_{\mathrm{U}}\right)$. Upstream and downstream river segments were delineated by the extent of the river corridor in each time step.

\subsection{GIS- and field-based analyses}

We have mapped fluvial forms and land cover types within each river segment and for each time step used in analysis using ArcGIS (ESRIC). Mapped fluvial forms included the river channel and major floodplain features such as abandoned meanders, oxbow lakes, and terraces (Fig. 4). In this paper, the term 'river corridor' encompasses the river channel

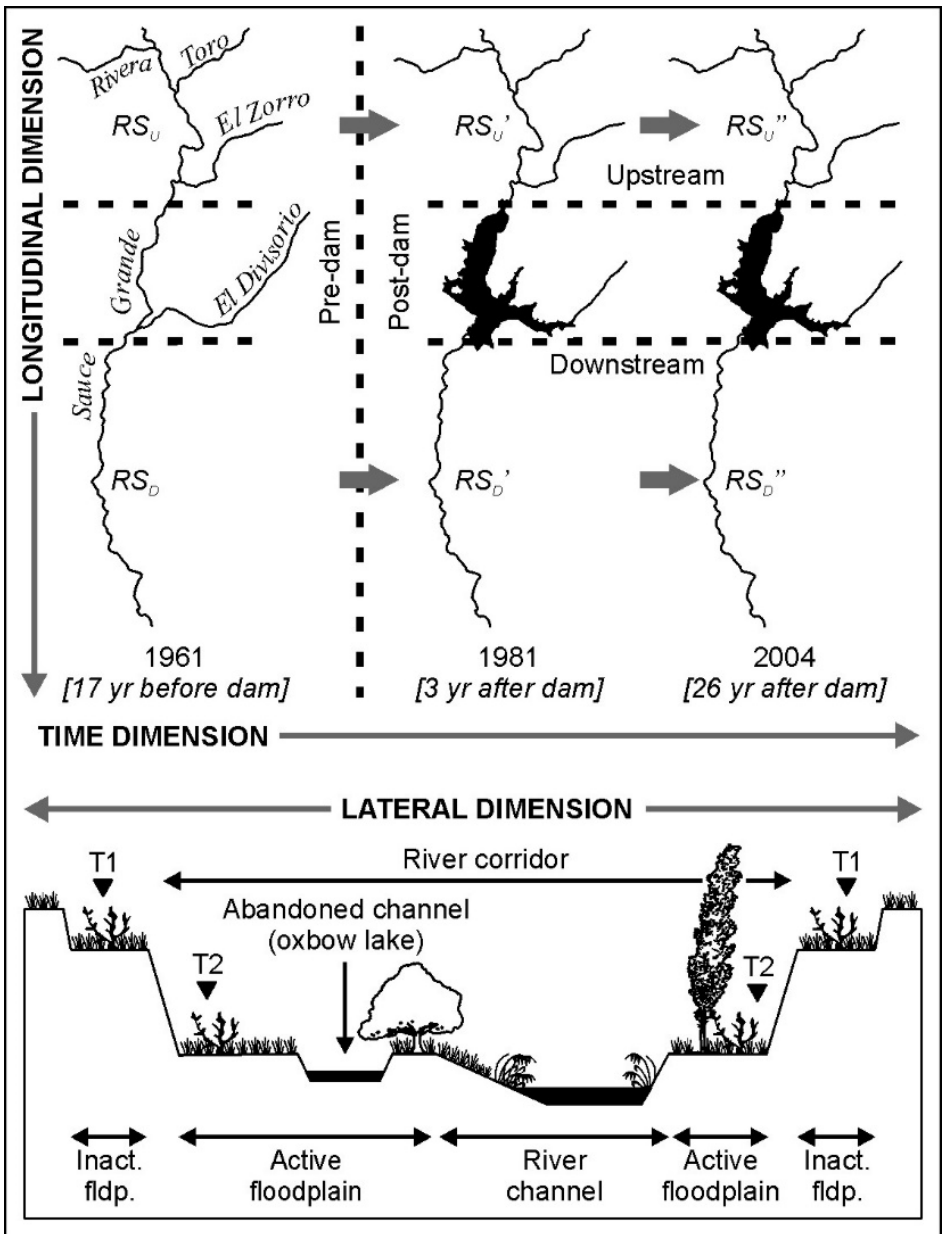


193 (delimited by the top portions of cutbanks and point bars) and the active floodplain, i.e., the

194 alluvial surface next to the channel, separated from the channel by banks, and built on

195 materials transported and deposited by the present regime of the river (Graf, 1988, p. 214).

196 Mapped land cover types include: (i) surfaces with none or little vegetation (bare surfaces);

197 (ii) surfaces covered by water; (iii) agricultural lands, including crops and pastures; (iv)

198 grasslands, dominated by graminoid species of Stipa and important associations of pampas

199 grasses (Cortaderia seollana); and (v) woodlands, clearly dominated by native species of

200 willow (Salix humbodltiana). In vegetation analysis, the term 'riparian vegetation' refers

201 explicitly to grasses and woods developing within the river corridor. Field-based analysis of

202 present channel conditions in the reference reaches used the stream reconnaissance scheme

203 devised by Thorne (1993) and included: (i) survey of the channel geometry (slope, planform,

204 and cross section); (ii) description of channel forms and materials, and (iii) interpretation of 205 vertical and lateral relations of channel to floodplain.

\subsection{Quantification of geomorphic and vegetation changes}

208 2.4.1. Geomorphic changes

209 Geomorphic analysis considered two aspects of the channel geometry: the channel planform

210 and the channel width as indicator of channel capacity. Quantification of planform change

211 used measures of channel activity (Wellmeyer et al., 2005). Overlay of channel bank lines

212 between consecutive time steps $\left[\mathrm{T}_{1}: \mathrm{T}_{2}\right]$ provided three distinct types of channel area: (i) the

213 area occupied during both time periods (planform stability), (ii) the area occupied only in the

214 second time step (channel creation), and (iii) the area occupied only in the first time step

215 (channel abandonment). Percent of channel stability, creation, and abandonment were

216 calculated relative to total channel area in $\mathrm{T}_{1}$. Rates of channel creation (or abandonment)

217 were calculated as channel area gained (or lost) in $\mathrm{T}_{1}: \mathrm{T}_{2}$ divided by the time interval length 
$218\left[T_{2}-T_{1}\right]$. To determine rates of stream lateral migration in terms of length per unit time

219 (Shields et al., 2000), we measured the area enclosed by successive stream centrelines (active

220 migration area, $A_{m}$ ). Rates of stream lateral migration were then calculated as the ratio of $A_{m}$

221 to the stream centreline length in $T_{1}$, divided by the time interval length $\left[T_{2}-T_{1}\right]$.

222 Quantification of width change used series of transects splitting the channel every $200 \mathrm{~m}$ of 223 channel length. This provided two types of measure: absolute channel width, given by the 224 length of each transect, and relative channel width, calculated as the area enclosed between 225 consecutive transects divided by channel length. Differences in width [w] between 226 consecutive time steps [ $\left.\mathrm{w}_{\mathrm{T} 2}-\mathrm{w}_{\mathrm{T} 1}\right]$ provided a net measure of channel narrowing (negative 227 differences) or widening (positive differences) along each river segment.

228 2.4.2. Vegetation changes

229 Changes in the composition of the fluvial corridor were inspected by overlaying successive 230 land cover maps. This provided a measure of the proportion $(\%)$ of riparian landscape gained 231 or lost by each land cover type. The direction and the strength of land cover changes with 232 time were assessed based on cross-tabulation of results and interpretation of transition 233 diagrams. Changes in riparian vegetation were measured in terms of (i) surface area gained or 234 lost by each vegetation type (changes in vegetation structure) and (ii) transitions to (or from) 235 other landscape units (vegetation dynamics). This permitted identification of patterns of 236 vegetation establishment (nature and extent) along the river course and with time.

238 2.5. Error analysis

239 Errors in quantification of geomorphic and vegetation change originate from (i) distortions in 240 the geometry of aerial photographs used as a data source and (ii) digitizing procedures.

241 Scanned aerial photographs were first corrected for scale and terrain distortions using ground 242 control point orthorectification in ErMapper. Orthorectification used high-resolution imagery 
243 (2004) and a 10-m contour-derived DEM (Casado et al., 2010). Orthorectified photographs

244 were then transformed in ArcGIS using the adjust transformation algorithm as it optimizes for

245 global and local accuracy. The RMSE from transformation of single photographs averaged

$2462.2 \mathrm{~m}(\mathrm{SD}=1.8 \mathrm{~m})$ for 1961 photographs and $1.2 \mathrm{~m}(\mathrm{SD}=1.0 \mathrm{~m})$ for 1981 photographs;

247 mean RMSE for all photographs was $1.7 \mathrm{~m}(\mathrm{SD}=1.5 \mathrm{~m})$. Errors associated with digitizing

248 procedures were estimated using the method of Downward (1994). Positional errors were

249 calculated from redigitizing the same feature 50 times using 2004 Ikonos imagery as source.

250 For a digitizing scale of 1:2500, errors averaged $0.7 \mathrm{~m}(\mathrm{SD}=0.4 \mathrm{~m})$. Mean errors from

251 transformation of the photographs and digitizing procedures can be accumulated to give a

252 total mean error of $2.4 \mathrm{~m}$. The total error margin for an exceedance probability of $10 \%$ is 4.8

$253 \mathrm{~m}$.

254

255 3. Results

256 3.1. Geomorphic change

257 3.1.1. Planform change

258 The unregulated river exhibited marked channel activity (Table 1; Fig. 5). Although new

259 channel surfaces were created by meander migration (10.6\%) and cutoff $(2.1 \%)$, the period

260 1961-1981 was characterized by abandonment of channel surfaces owing to meander

261 translation (15.1\%; Fig. 5, Ex. 1) and abandonment of meander bends (3.1\%; Fig. 5, Ex. 2).

262 Channel activity during the period 1981-2004 was clearly dominated by meander extension

263 and translation. High percentages of channel abandonment (19.8\%) indicate a tendency to

264 channel straightening. Yet increased bend amplitude in some river sections was notable (Fig.

265 5, Ex. 3), and three major cutoffs in the middle-lower river segment (Fig. 5, Ex. 4) give

266 evidence of the geomorphic effectiveness of floods during the second comparative period. 
269 Rates of channel and stream activity within the unregulated and regulated river segments by comparative period

\begin{tabular}{llcccc}
\hline & & \multicolumn{2}{c}{ Unregulated river segment } & \multicolumn{2}{c}{ Regulated river segment } \\
\cline { 3 - 6 } Channel migration $\left(\mathrm{m}^{2} 10^{-2}\right)$ & $1961-1981$ & $1981-2004$ & $1961-1981$ & $1981-2004$ \\
\hline \multirow{2}{*}{$\begin{array}{l}\text { Channel } \\
\text { creation }\end{array}$} & By lateral migration & 52.3 & 49.2 & 3.3 & 3.3 \\
& Meander cutoff & 10.2 & 4.1 & 1.1 & 1.1 \\
\hline \multirow{2}{*}{$\begin{array}{l}\text { Channel } \\
\text { abandonment }\end{array}$} & By lateral migration & 74.7 & 81.2 & 7.9 & 7.9 \\
\cline { 2 - 6 } & Abandoned bends & 15.1 & 11.1 & 5.5 & 5.5 \\
\hline \multicolumn{2}{l}{ Stream lateral migration $\left(m^{-1}\right)$} & 0.31 & 0.26 & 0.02 & 0.06 \\
\hline
\end{tabular}

Conversely, the river channel below the dam exhibited marked planform stability during both comparative periods (93 to 97\%). Channel activity during the period 1961-1981 was closely related to waterworks conducted in the vicinity of the dam (e.g., deviation of the river course

274 from its original position to the dam outlet; Fig. 5, Ex. 5). Localized translation of meander

275 bends occurred in the middle-upper river segment, and two abandoned bends were observed 276 at river km 2 and 13 below the dam. Whereas the cutoff morphology in the first case suggests 277 a human-related origin, the latter was conceivably cutoff by high flows occurring during the 278 pre-disturbance phase (Fig. 5, Ex. 6). Meander cutoff and abandonment of meander bends 279 were dominant processes during the post-disturbance phase (1981-2004). Yet four out of five 280 cutoffs displayed a human-related origin (e.g., two major cutoffs facilitate canalization of dam 281 spills; Fig. 5, Ex. 7). Percentage of channel abandonment was five times that of channel 282 creation (7.4 and $1.4 \%$, respectively), and the channel sinuosity was reduced by $2.7 \%$.

\subsubsection{Width change}

284 Upstream from the dam, coupled channel widening and narrowing occurred during both 285 comparative periods with a tendency to narrowing during the second comparative period (Fig. 286 6). Width changes occurred most likely in river sections exhibiting active lateral migration. 287 Thus, many channel sections narrowed owing to lateral accretion and outward migration of 
meander bends (up to $50 \%$ during 1961-1981, and up to $60 \%$ during 1981-2004), and river

289 sections dominated by cut bank erosion increased in width by up to 62\% (1961-1981) and 55\% (1981-2004). Below the dam, the channel revealed a tendency to narrowing during both

291 comparative periods (Fig. 6). The period 1961-1981 was characterized by marked contraction 292 of the channel width (12 to $33 \%$ ) owing to deviation and artificial straightening of the river 293 course in the vicinity of the impoundment. During the period 1981-2004, the channel width 294 contracted in 31 sites ( $15 \%$ of cases). The percentage of channel narrowing decreased in the downstream direction from 44 to $4 \%$ and responded to two distinct, localized processes.

296 Immediately below the dam and over $\sim 4$ river $\mathrm{km}$, the channel narrowed by between 9 and $44 \%$ owing to artificial meander cutoff, building of artificial levees, and other dam-related waterworks. Downstream from river $\mathrm{km} \mathrm{4}$, the position of bank lines remained relatively unchanged. However, contraction of the channel width (6 to 30\%) was inferred by vegetation encroachment over former bare channel surfaces.

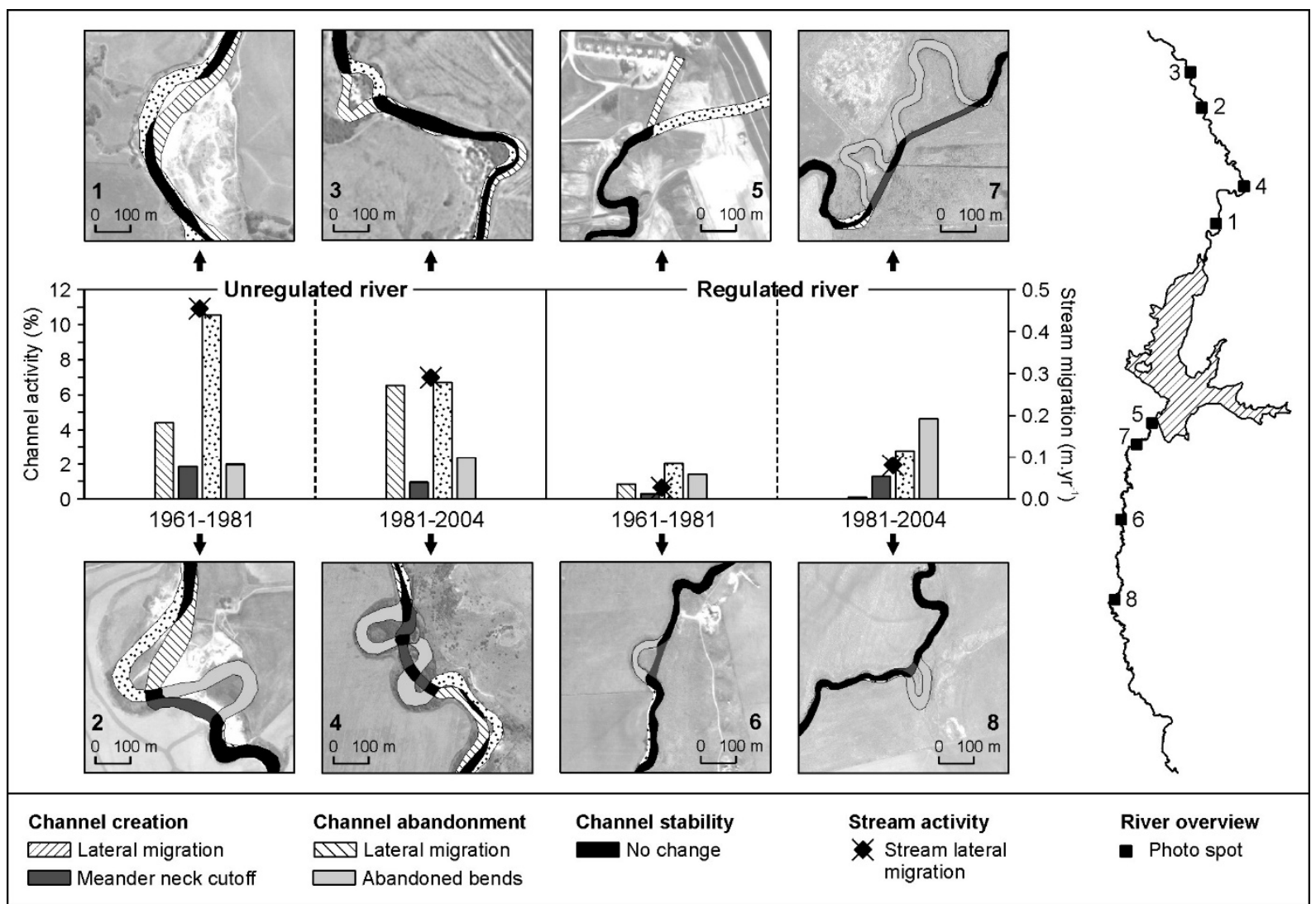

Fig. 5. Channel and stream activity within the unregulated and regulated river segments by 
comparative period. Boxes provide an overview of major planform changes above and below
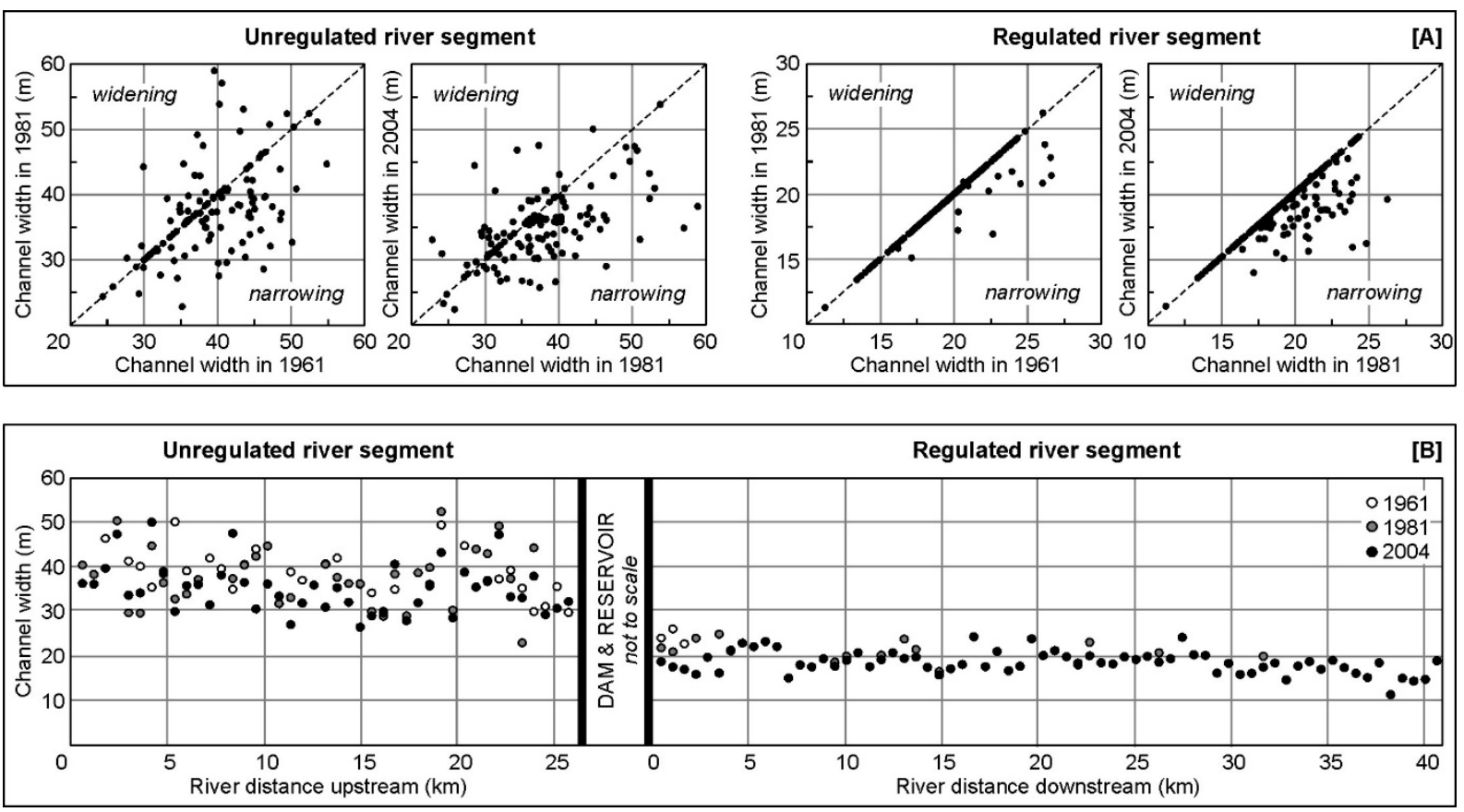

Fig. 6. [A] Scatterplots comparing the river channel width between consecutive time steps, and $[\mathrm{B}]$ river channel width as a function of time and distance downstream. Channel width was calculated as a function of channel area divided by $200-\mathrm{m}$ length along each river segment. The hashed central line in $[\mathrm{A}]$ indicates a situation of no change between consecutive time steps. Data in [B] were reduced to improve readability (1 point every $600 \mathrm{~m}$

\subsection{Vegetation changes}

316 An overall tendency to vegetation growth was observed simultaneously upstream and

317 downstream from the dam (Table 2). Yet there were marked upstream-downstream

318 differences concerning (i) the spatial extent of vegetation growth, (ii) the nature of vegetation 319 transitions, and (iii) the patterns of vegetation establishment. 
320 First, the expansion of woodlands within the river corridor downstream from the dam was

321 four times smaller than that observed within the unregulated river upstream (91 and 397\%

322 between 1961 and 2004, respectively), and the surface area occupied by woodlands in 2004

323 was $53 \%$ of that observed upstream (Table 2). Yet the proportion of woodlands as percentage

324 of total river corridor surface area in 2004 was similar for both river environments (23 and

$32528 \%$, respectively).

326 Table 2

327 Surface area by land cover type within the unregulated and regulated river segments per time

328 step; rates of change with time were calculated based on absolute surface differences per time

329 interval; highest percentages of change by cover type are indicated in bold

\begin{tabular}{llllllll}
\hline & \multicolumn{3}{c}{ Surface area (ha) } & \multicolumn{2}{c}{ Difference (ha) } & \multicolumn{2}{c}{ Rate of change (\%) } \\
\cline { 2 - 7 } Cover type & 1961 & 1981 & 2004 & $1961-81$ & $1981-04$ & $1961-81$ & $1981-04$ \\
\hline
\end{tabular}

Unregulated river segment upstream from the dam

\begin{tabular}{|c|c|c|c|c|c|c|c|}
\hline Agricultural lands & 24.9 & 10.7 & 8.8 & -14.2 & -1.9 & -57.0 & -18.0 \\
\hline Water surfaces & 50.4 & 149.9 & 157.3 & 99.4 & 7.4 & 197.1 & 4.9 \\
\hline Bare soils & 66.1 & 33.3 & 10.9 & -32.8 & -22.4 & -49.6 & -67.3 \\
\hline Grasslands & 250.2 & 192.7 & 121.8 & -57.5 & -70.9 & -23.0 & -36.8 \\
\hline Woodlands & 23.4 & 28.5 & 116.4 & 5.1 & 87.9 & 21.8 & 308.0 \\
\hline \multicolumn{8}{|c|}{ Regulated river segment downstream from the dam } \\
\hline Agricultural lands & 12.7 & 45.1 & 86.8 & 32.4 & 41.6 & 255.2 & 92.2 \\
\hline Water surfaces & 28.8 & 26.9 & 20.8 & -1.9 & -6.1 & -6.6 & -22.7 \\
\hline Bare soils & 1.0 & 2.1 & 0.2 & 1.1 & -1.9 & 102.4 & -92.8 \\
\hline Grasslands & 191.3 & 155.5 & 96.5 & -35.8 & -59.0 & -18.7 & -37.9 \\
\hline Woodlands & 32.4 & 36.6 & 62.0 & 4.2 & 25.4 & 12.9 & 69.3 \\
\hline
\end{tabular}

330 Second, the river corridors upstream and downstream from the dam revealed contrasting

331 trends in vegetation dynamics (Fig. 7). Other than the expansion of agricultural lands over

332 grasslands (583\% between 1961 and 2004; Table 2), the most important transitions

333 downstream occurred from water surfaces to woodlands (38\%). This suggests a tendency for

334 woody vegetation establishment within the river channel, near to the water surface. A

335 moderated tendency for woody vegetation growth over former bare banks (18\%) and 
grasslands (16\%) was also identified. Yet the expansion of woodlands over these landscape units was notably less significant than that observed within the river corridor upstream from the dam (Fig.7). Upstream, woodlands expanded within the river channel and the floodplain, covering $33 \%$ of former grasslands and $57 \%$ of former bare banks.

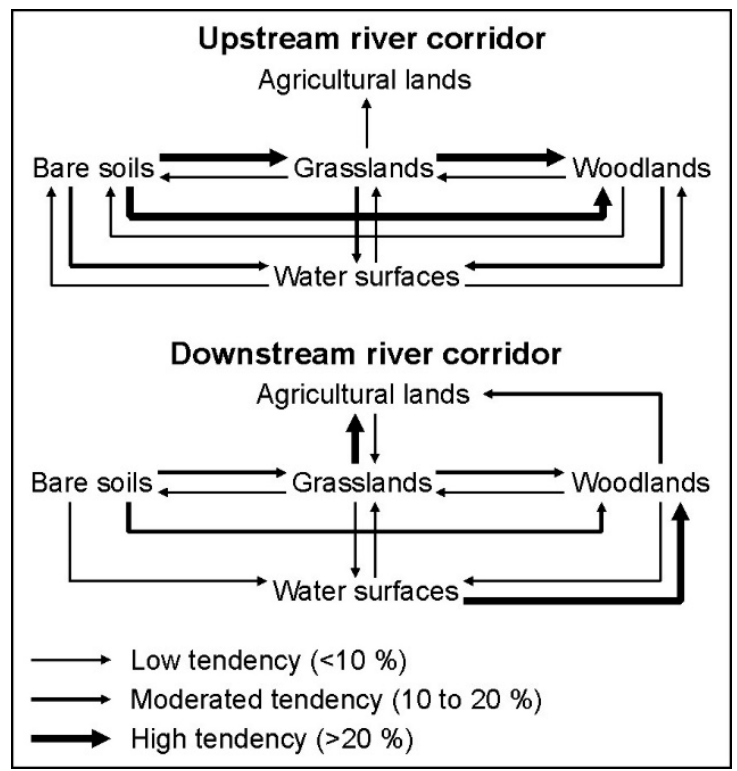

Fig. 7. Trends in vegetation dynamics within the river corridors upstream and downstream from the Paso de las Piedras Dam. Trends were calculated from transitional diagrams of landscape units by comparative period.

Third, woody vegetation establishment within the river corridor downstream from the dam was discontinuous, decreased in the downstream direction, and constrained almost exclusively to the river channel. Analysis at the scale of the reference reaches (Fig. 8) revealed three distinct patterns of woody vegetation establishment with distance from dam closure: (i)

348 immediately downstream from the dam and over $\sim 10$ river $\mathrm{km}$, woody vegetation develops

349 within the channel and adjacent to the water surface forming extensive and continuous 350 alignments (e.g., R4 and R5); (ii) downstream thereafter, woody vegetation develops in a 351 narrow and discontinuous strip along the stream over 20 river km (e.g., R6 and R7); (iii) downstream from river $\mathrm{km} \mathrm{30,} \mathrm{channel} \mathrm{vegetation} \mathrm{is} \mathrm{dominated} \mathrm{by} \mathrm{grasslands} \mathrm{and} \mathrm{alternating}$

353 alignments of young willows developing near the water surface (e.g., R8). 


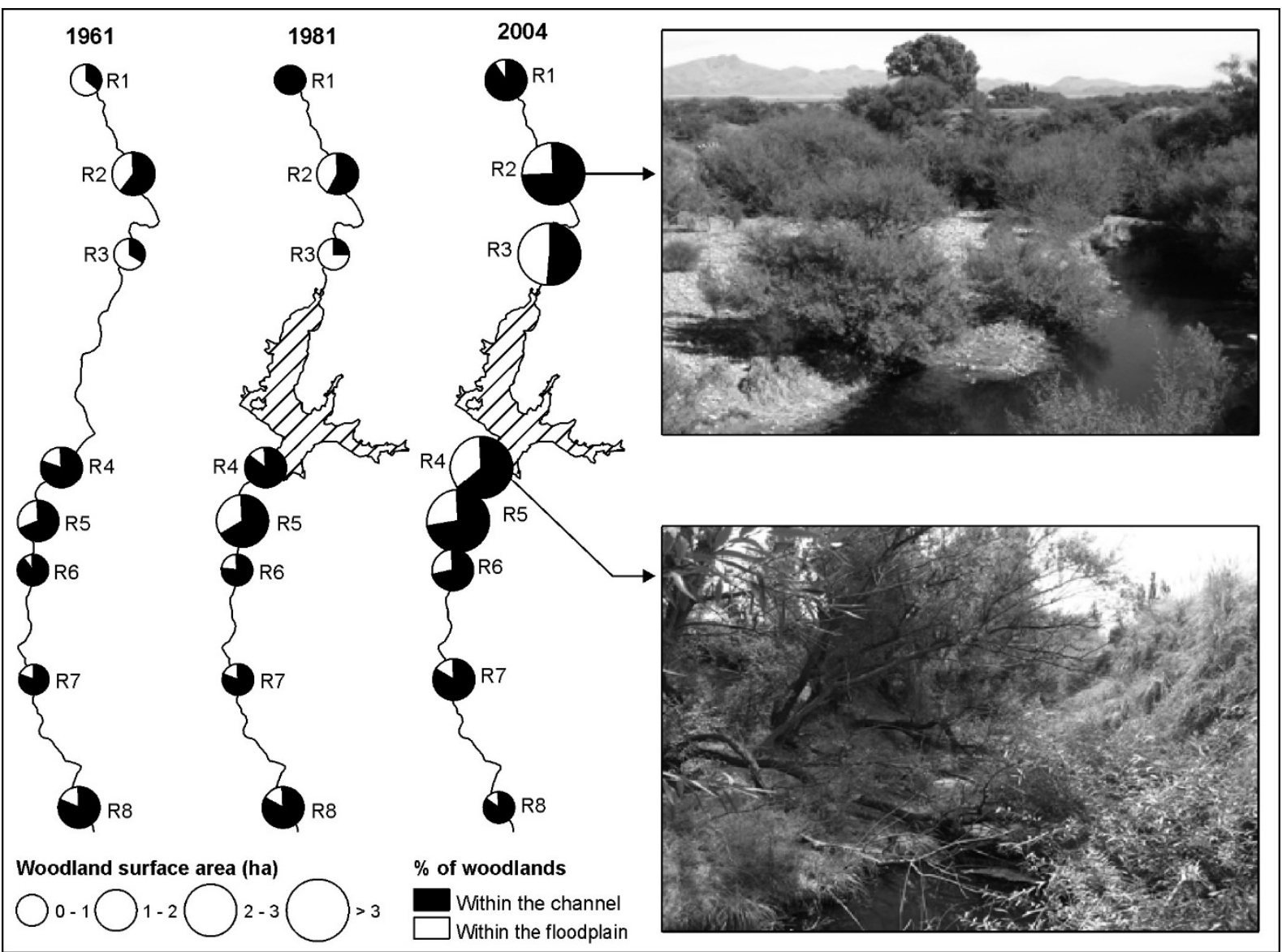

Fig. 8. Surface area occupied by woodlands by river reach $(\mathrm{R})$ and time step. Pie charts differentiate percentages of woody vegetation developing within the river channel and the upstream and downstream from the dam.

\subsection{Present channel conditions}

361 Present channel forms clearly differentiate river reaches located above and below the dam.

362 The river channel above the dam (Fig. 9) is broad and shallow $(27<w: d<37)$, and the

363 floodplain is well developed for much of the river course. Channel width averages $53 \mathrm{~m}( \pm 16$

$364 \mathrm{~m})$, and floodplain width averages $135 \mathrm{~m}$ with high variation $( \pm 94 \mathrm{~m})$. The channel

365 morphology is clearly meandering for all reaches; variations in sinuosity $(1.1<1.5)$, meander

366 wavelength $(150 \mathrm{~m}<600 \mathrm{~m})$, and meander width $(20 \mathrm{~m}<200 \mathrm{~m})$ are probably linked to local

367 variations in slope and degree of confinement within the incised valley. Bed material is coarse 
in riffles (cobbles and coarse gravel) and finer in pools (small gravels, sand and silt); banks

369 are composed of noncohesive deposits in point bars (sand and gravel) and of layered,

370 cohesive paleofluvial and aeolian deposits in cut banks (fine sand, silt and clay). Bank profiles

371 reveal active cut bank erosion including bank undercut and toe scour (especially in R3; Fig.

372 9); channel sections exhibiting vertical banks display coupled toe accumulation by mass

373 wasting. Lateral accretion in point bars is a more dominant process. Outward migration of the

374 meanders led to formation of terrace steps contained within the valley, and hence

375 topographically lower than the preincision surface.

376 The river channel below the dam is narrow and deep $(7<w: d<10)$, and the floodplain is

377 much reduced (Fig. 10). Mean channel width is $21 \mathrm{~m} \mathrm{(} \pm 6 \mathrm{~m})$, and mean floodplain width is 53

$378 \mathrm{~m}( \pm 30 \mathrm{~m})$. Except for R5 where meanders are very tortuous $(S=2.8)$, sinuosity increases in

379 the downstream direction from 1.3 to 2.2. Bed material is composed of small gravel in riffles

380 and of silt/clay in pools; banks exhibit cohesive layers of fine 'spring' and ephemeral fluvial-

381 aeolian deposits. Bank profiles display stable conditions for most river reaches, except for R4

382 where mass wasting occurs in vertical banks with little vegetation cover. Immediately below

383 the dam, any evidence of channel activity is related to human intervention. For example,

384 artificial bed deepening in R4 facilitates evacuation of dam outlets and spills, and artificial

385 levees (built by dredging floodplain material) prevent bank overflowing. Outside the vicinity

386 of the impoundment, bed deposition of very fine materials (silt/clay and organic matter) leads

387 to localized reduction of the channel depth (e.g., R6; Fig. 10). 


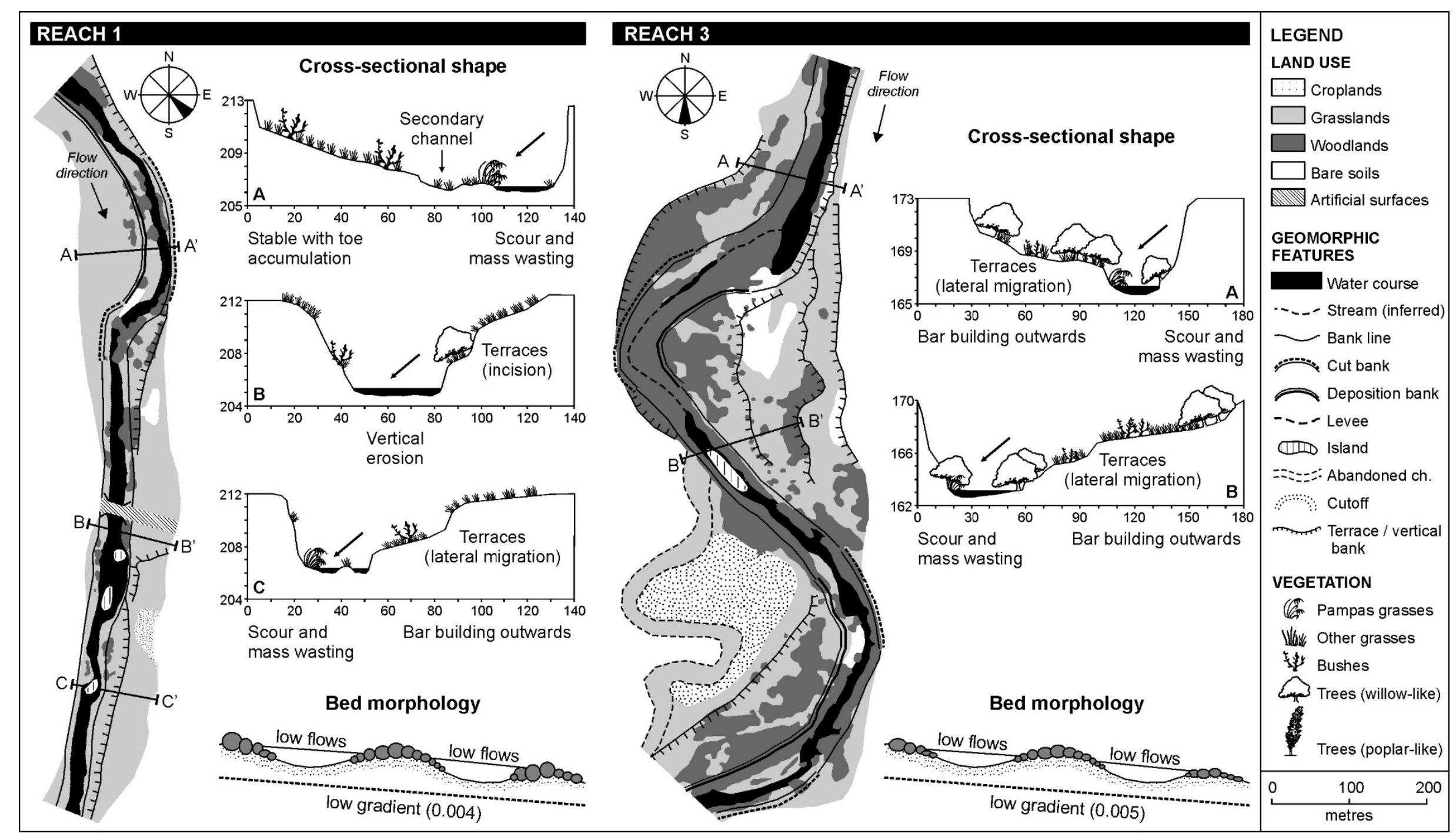

Fig. 9. Geomorphic features, land cover types, and representative cross sections for two reference reaches located upstream from the Paso de las Piedras Dam. The locations of the reference reaches along the unregulated river segment upstream are shown in Fig. 1. 


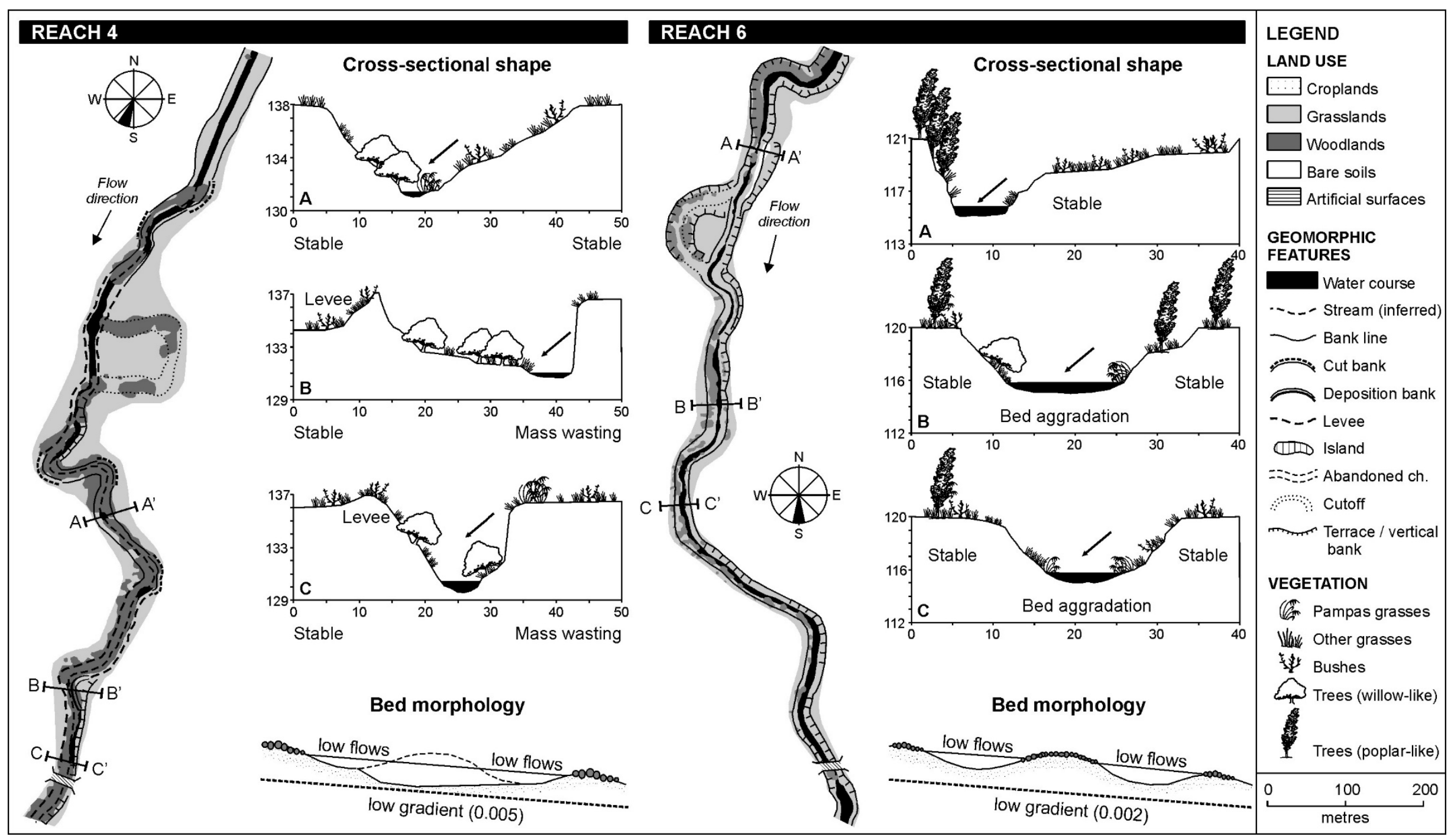

Fig. 10. Geomorphic features, land cover types, and representative cross sections for two reference reaches located downstream from the Paso de las Piedras Dam. The locations of the reference reaches along the regulated river segment downstream are shown in Fig.1. 


\section{Discussion}

\subsection{Geomorphic response of the Sauce Grande River to flow regulation}

390 The construction and operation of the Paso de las Piedras Dam led to substantial changes in

391 the hydrology of the Sauce Grande River downstream. The frequency and magnitude of

392 floods were dramatically reduced, and the permanence of low flows increased significantly.

393 Although the sediment trapping efficiency of the reservoir may be assumed as near $100 \%$

394 (Petts, 1984; Williams and Wolman, 1984), this study postulates that under conditions of

395 extreme reduction in flow discharge, the impacts of the dam on the sediment transport

396 capacity of the stream were more significant than those on the sediment load.

397 If reduction in flow discharge is greater than that in sediment load, then one would expect a

398 dominance of aggradation processes over erosion and scour (Petts, 1979; Brandt, 2000), as

399 well as a tendency to channel narrowing and vegetation encroachment over bank deposits

400 increasing the channel roughness (Petts and Gurnell, 2005). The geomorphic response of the

401 Sauce Grande River, however, was characterized by (i) marked channel stability, (ii)

402 vegetation encroachment reflecting (and influencing) channel stability, and (iii) localized

403 reduction of the pre-dam channel capacity owing to vegetation growth. The following

404 sections expand on these findings and compare the geomorphic response of the Sauce Grande

405 River to other impounded rivers in dryland regions (Table 3).

\subsubsection{Channel stability}

407 One of the most common consequences of impoundment of meandering rivers in drylands is

408 the reduction of lateral migration rates (e.g., the upper Missouri and many other meandering

409 rivers within the American Great Plains; Table 3). Within the regulated Sauce Grande,

410 however, lateral channel migration was not reduced but inhibited. Any evidence of lateral

411 channel activity constrained to the phase of pre- and early disturbance and major planform

412 changes observed during the post-disturbance phase - such as meander cutoff and 
413 abandonment of meander bends - revealed a human-related origin in $80 \%$ of cases. Planform

414 stability has been reported for very few meandering rivers (e.g., the lower Murray; Table 3)

415 and appears to be a more common consequence within regulated braided rivers (e.g., Orange

416 and Durance rivers; Table 3).

417 Moreover, studies on impounded dryland rivers subject to reduced and overloaded flows have

418 reported a substantial reduction of the channel capacity owing to lateral and vertical accretion

419 (e.g., Rio Grande, Green, and Medjerda rivers; Table 3). In opposition, the regulated Sauce

420 Grande displayed relative stability of the channel cross section. A marked contraction of the

421 channel width was apparent over the first 4 river $\mathrm{km}$ below the dam closure. Yet channel

422 narrowing was closely linked to deviation and artificial straightening of the river course,

423 building of artificial levees, and other dam-related waterworks. Downstream from river km 4,

424 the position of bank lines remained relatively unchanged for the three time steps used in

425 photointerpretation analysis (i.e., a true reduction of the channel width by redistribution of

426 sediment within the channel was not observed). Channel narrowing was inferred, however, by

427 vegetation growth within the channel. Changes in channel depth involved localized deposition

428 of very fine materials (silt/clay and organic matter). Although bed aggradation conceivably

429 led to local variations in channel depth and slope, sediment deposition is negligible compared

430 to that commonly reported in literature and will rapidly reverse during the next episode of

431 flow release.

432 Table 3

433 Examples of geomorphic changes of regulated dryland rivers by world region

\begin{tabular}{|c|c|c|c|c|}
\hline River & Impoundment & Purpose & Channel adjustments* & Citation \\
\hline
\end{tabular}

North America

Colorado Glen Canyon Multipurpose $\mathrm{d}^{+/}$, bed armouring/aggradation, w, Howard and

(Colorado) (1963) CC $\mathrm{CC}^{-}, \mathrm{s}^{-}$, marsh development Dolan (1981);

Stevens et al.

(1995); Grams

et al. (2007) 


\begin{tabular}{|c|c|c|c|c|}
\hline $\begin{array}{l}\text { Green } \\
\text { (Colorado; } \\
\text { Utah) }\end{array}$ & $\begin{array}{l}\text { Flaming } \\
\text { Gorge (1962) }\end{array}$ & Hydropower & $\begin{array}{l}\mathrm{d}^{-}, \mathrm{w}^{-/+}, \mathrm{n}^{+} \text {(vegetation encroachment), } \\
\text { bar stabilisation, island formation, } \\
\text { terrace formation, planform change } \\
\text { from meandering to shallow braided }\end{array}$ & $\begin{array}{l}\text { Andrews } \\
\text { (1986); Merritt } \\
\text { and Cooper } \\
\text { (2000); Grams } \\
\text { and Schmidt } \\
\text { (2002) }\end{array}$ \\
\hline $\begin{array}{l}\text { Dry Creek } \\
\text { (California) }\end{array}$ & $\begin{array}{l}\text { Warm Springs } \\
(1982)\end{array}$ & Multipurpose & $\begin{array}{l}\mathrm{d}^{+}, \mathrm{w}^{-}, \mathrm{CC}^{-}, \text {lateral migration } \\
\text { (vegetation encroachment) }\end{array}$ & $\begin{array}{l}\text { Gordon and } \\
\text { Meentemeyer } \\
\text { (2006) }\end{array}$ \\
\hline $\begin{array}{l}\text { Bill } \\
\text { Williams }\end{array}$ & Alamo (1968) & Flood control & $\begin{array}{l}\mathrm{w}^{-}, \mathrm{CC}^{-}, \mathrm{n}^{+} \text {(vegetation encroachment), } \\
\text { invasion of exotic species }\end{array}$ & $\begin{array}{l}\text { (Shafroth et al. } \\
(2002) \text {; } \\
\text { Stromberg et } \\
\text { al. (2012) }\end{array}$ \\
\hline Great Plains & Several & Multiple & $\begin{array}{l}\mathrm{w}^{-} \text {(braided rivers), lateral migration } \\
\text { (meandering rivers), vegetation } \\
\text { growth/decrease relative to fluvial } \\
\text { style }\end{array}$ & $\begin{array}{l}\text { Friedman et al. } \\
\text { (1998) }\end{array}$ \\
\hline $\begin{array}{l}\text { Upper } \\
\text { Missouri } \\
\text { (Montana) }\end{array}$ & $\begin{array}{l}\text { Fort Peck } \\
(1940)\end{array}$ & $\begin{array}{l}\text { Hydropower; } \\
\text { flood control }\end{array}$ & $\begin{array}{l}\mathrm{d}^{+}, \mathrm{w}^{-}, \text {bank unstability } \\
\text { migration }\end{array}$ & $\begin{array}{l}\text { Darby and } \\
\text { Thorne (2000); } \\
\text { Shields et al. } \\
\text { (2000); Simon } \\
\text { et al. (2002) }\end{array}$ \\
\hline \multirow[t]{2}{*}{$\begin{array}{l}\text { Rio Grande } \\
\text { (New } \\
\text { Mexico) }\end{array}$} & $\begin{array}{l}\text { Cochiti } \\
(1973)\end{array}$ & $\begin{array}{l}\text { Flood / } \\
\text { sediment } \\
\text { control }\end{array}$ & $\begin{array}{l}\mathrm{d}^{+}, \text {bed coarsening, } \mathrm{w}^{-}, \mathrm{S}^{+} \text {, bars and } \\
\text { islands reduced, planform changes } \\
\text { from braided to meandering, channel- } \\
\text { floodplain disconnection }\end{array}$ & $\begin{array}{l}\text { Richard and } \\
\text { Julien (2003) }\end{array}$ \\
\hline & $\begin{array}{l}\text { Elephant } \\
\text { Butte } \\
(1915)\end{array}$ & $\begin{array}{l}\text { Irrigation; } \\
\text { hydropower }\end{array}$ & $\begin{array}{l}\mathrm{d}^{+-}, \mathrm{w}^{-} \text {(lateral accretion), } \mathrm{CC}^{-} \text {, terrace } \\
\text { formation, meander cutoff, } \\
\text { disconnection from tributaries }\end{array}$ & $\begin{array}{l}\text { Everitt (1993); } \\
\text { Schmidt and } \\
\text { Everitt (2000) }\end{array}$ \\
\hline
\end{tabular}

\section{Mediterranean Basin}

\begin{tabular}{|c|c|c|c|c|}
\hline $\begin{array}{l}\text { Medjerda } \\
\text { (Tunisia) }\end{array}$ & $\begin{array}{l}\text { Sidi Salem } \\
(1981)\end{array}$ & Flood control & $\begin{array}{l}\mathrm{d}^{-}, \mathrm{w}^{-}, \mathrm{CC}^{-}, \mathrm{n}^{+} \text {(vegetation } \\
\text { encroachment) }\end{array}$ & $\begin{array}{l}\text { Zahar et al. } \\
(2008)\end{array}$ \\
\hline $\begin{array}{l}\text { Ebro } \\
\text { (Spain) }\end{array}$ & $\begin{array}{l}\text { Ebro (1945); } \\
\text { Yesa (1959) }\end{array}$ & $\begin{array}{l}\text { Water supply; } \\
\text { irrigation; } \\
\text { hydropower; }\end{array}$ & $\begin{array}{l}\mathrm{w}^{-}, \text {river corridor width', lateral } \\
\text { migration- } \mathrm{n}^{+} \text {(vegetation encroach- } \\
\text { ment) }\end{array}$ & $\begin{array}{l}\text { Magdaleno } \\
\text { and Fernandez } \\
(2010)\end{array}$ \\
\hline $\begin{array}{l}\text { Durance } \\
\text { (France) }\end{array}$ & $\begin{array}{l}\text { Serre Ponçon } \\
\text { (1960) and } \\
\text { others }\end{array}$ & $\begin{array}{l}\text { Hydropower } \\
\text { irrigation ; } \\
\text { water supply }\end{array}$ & $\begin{array}{l}\mathrm{d}^{-}, \mathrm{w}^{-}, \mathrm{CC}^{-}, \mathrm{n}^{+} \text {(vegetation } \\
\text { encroachment), planform stability }\end{array}$ & $\begin{array}{l}\text { Lefort and } \\
\text { Chapuis } \\
(2012)\end{array}$ \\
\hline \multicolumn{5}{|c|}{ Central Asia } \\
\hline $\begin{array}{l}\text { Yellow } \\
\text { (China) }\end{array}$ & $\begin{array}{l}\text { Sanmenxia } \\
(1960)\end{array}$ & $\begin{array}{l}\text { Flood and } \\
\text { sediment } \\
\text { control }\end{array}$ & $\begin{array}{l}\mathrm{d}^{-/+}, \mathrm{w}^{-/+}, \mathrm{CC}^{-}, \mathrm{s}^{+/-}, \mathrm{S}^{+}, \\
\text {Planform changes from braided to } \\
\text { wandering and from wandering- } \\
\text { braided to wandering-meandering } \\
\text { (direction of channel adjustment } \\
\text { varies with time) }\end{array}$ & $\begin{array}{l}\text { Chien (1985); } \\
\text { Wang and Hu } \\
\text { (2004); Wang } \\
\text { et al. (2007); } \\
\text { Ma et al. } \\
\text { (2012) }\end{array}$ \\
\hline
\end{tabular}

Australia 


\begin{tabular}{|c|c|c|c|c|}
\hline $\begin{array}{l}\text { Cudgegong } \\
\text { (NSW) }\end{array}$ & $\begin{array}{l}\text { Windamere } \\
\text { (1984) }\end{array}$ & $\begin{array}{l}\text { Irrigation; } \\
\text { water supply }\end{array}$ & $\begin{array}{l}\mathrm{d}^{+/-}, \text {localized bed coarsening-fining, } \\
\mathrm{w}^{-/ \mathrm{o}}, \mathrm{CC}^{-}, \mathrm{n}^{+} \text {(vegetation encroach- } \\
\text { ment) }\end{array}$ & $\begin{array}{l}\text { Benn and } \\
\text { Erskine (1994) }\end{array}$ \\
\hline $\begin{array}{l}\text { Mangrove } \\
\text { Creek } \\
\text { (NSW) }\end{array}$ & $\begin{array}{l}\text { Mangrove } \\
\text { Creek (1981) }\end{array}$ & Water supply & $\begin{array}{l}\mathrm{d}^{+-}, \mathrm{w}^{-} \text {(lateral accretion), } \mathrm{CC}^{-}, \mathrm{n}^{+} \\
\text {(vegetation encroachment) }\end{array}$ & $\begin{array}{l}\text { Sherrard and } \\
\text { Erskine (1991) }\end{array}$ \\
\hline $\begin{array}{l}\text { Upper } \\
\text { Murray } \\
\text { (NSW) }\end{array}$ & $\begin{array}{l}\text { Hume }(1925) \text {; } \\
\text { Dartmouth } \\
\text { (1928) }\end{array}$ & $\begin{array}{l}\text { Irrigation; } \\
\text { water supply }\end{array}$ & $\begin{array}{l}\mathrm{d}^{+}, \mathrm{w}^{+} \text {(bank erosion), lateral } \\
\text { migration }{ }^{+} \text {, anabranching }\end{array}$ & $\begin{array}{l}\text { Tilleard et al. } \\
\text { (1994) }\end{array}$ \\
\hline $\begin{array}{l}\text { Lower } \\
\text { Murray } \\
\text { (SA) }\end{array}$ & Locks $2 \& 3$ & $\begin{array}{l}\text { Navigation; } \\
\text { irrigation }\end{array}$ & $\mathrm{d}^{+/-}, \mathrm{w}^{-/+}, \mathrm{s}^{0 /+/-}$, planform stability & $\begin{array}{l}\text { Thoms and } \\
\text { Walker (1993) }\end{array}$ \\
\hline \multicolumn{5}{|l|}{ South Africa } \\
\hline Orange & $\begin{array}{l}\text { Vanderkloof } \\
\text { \& Gariep } \\
(1970 ’ s)\end{array}$ & $\begin{array}{l}\text { Hydropower; } \\
\text { irrigation }\end{array}$ & $\begin{array}{l}\text { Main channel planform stability, } \\
\text { filling of secondary braids, } \mathrm{n}^{+} \\
\text {(vegetation encroachment) }\end{array}$ & $\begin{array}{l}\text { Blanchon and } \\
\text { Bravard (2007) }\end{array}$ \\
\hline \multicolumn{5}{|c|}{ South America } \\
\hline $\begin{array}{l}\text { Chubut } \\
\text { (Argentina) }\end{array}$ & $\begin{array}{l}\text { Florentino } \\
\text { Ameghino } \\
\text { (1963) }\end{array}$ & Hydropower & $\begin{array}{l}\mathrm{d}^{+}, \mathrm{w}^{-} \text {(lateral accretion), } \mathrm{CC}^{-}, \mathrm{n}^{+} \\
\text {(vegetation encroachment), terrace } \\
\text { formation }\end{array}$ & $\begin{array}{l}\text { Kaless et al. } \\
(2008)\end{array}$ \\
\hline $\begin{array}{l}\text { San Juan } \\
\text { (Argentina) }\end{array}$ & Ullum & Multipurpose & $\begin{array}{l}\mathrm{d}^{+} \text {, localized armouring, bed } \\
\text { instability, } \mathrm{s}^{-/+}\end{array}$ & $\begin{array}{l}\text { Grimalt and } \\
\text { Grimalt (2005) }\end{array}$ \\
\hline
\end{tabular}

* [d] is channel depth, [w] is channel width, [CC] is channel capacity, [n] is channel roughness, [s] is channel slope, and $[\mathrm{S}]$ is stream sinuosity. The direction of change is indicated by $[0]$ no significant change, $[+]$ increase, and [-] decrease.

Two interrelated processes explain marked planform and cross section stability in the river

438 section below the dam. First, the morphology of the unregulated Sauce Grande is driven by

439 floods of high relative magnitude and low frequency common to most dryland rivers (Graf,

440 1988; Tooth, 2000b; Nanson et al., 2002; Tooth, 2013). Since the Paso de las Piedras Dam

441 retains nearly the full range of floods, the processes promoting migration of meanders bends

442 and adjustments of the channel cross section downstream were heavily truncated. As a result,

443 the broad morphology of the regulated Sauce Grande remained unchanged since dam closure

444 and is likely to exhibit stable conditions until a geomorphically significant flow event occurs.

445 Second, reduction of the magnitude and frequency of morphogenetic flows should promote

446 channel aggradation. However, and as reported by Petts (1979), channel aggradation below

447 dams requires introduction of sediment from tributaries and/or redistribution of sediment 
within the channel. Within the regulated Sauce Grande both processes are unlikely. The river

449 below the dam flows for the majority of its course without influence of tributaries and, in the

450 absence of reservoir discharges, sources for water and sediment are limited to (i) reservoir

451 seepage, (ii) groundwater inflows, and (iii) overland flow along the river course. Combined

452 with the endogenous production of organic matter, these processes could explain bed

453 deposition of very fine materials. On the other hand, redistribution of sediment within the

454 regulated river channel is unlikely because the regulated flow is incompetent to rework the

455 pre-dam channel forms.

\subsubsection{Vegetation dynamics}

In opposition to what was expected, results revealed a synchronized tendency to afforestation of the river corridor upstream and downstream from the dam. Vegetation growth involved establishment of woody species such as willows (Salix humboldtiana, native species) and poplars (Populus sp., exotic species) and conceivably responded to a cycle of wetter climate that affects central-eastern Argentina since the 1970s (Penalba and Vargas, 2004). As argued by Braatne et al. (2008), cycles of dry and wet climate drive episodes of decline and recovery

463 in riparian communities, and the authors outlined that these natural cycles provide a variable

464 baseline upon which impacts of damming and flow-regulation are superimposed (p. 278).

465 Moreover, results revealed that the extent of the riparian zone downstream from the dam has

466 been reduced for much of the river course (and keeps reducing) because of the progression of 467 agricultural lands over the floodplain. The interacting influence of land use changes appends a 468 second factor superimposing the effects of dam operation on riparian vegetation.

469 Irrespective of climate and land use changes influencing vegetation dynamics at the scale of 470 the river basin, vegetation structure and successions along the river corridor are primarily 471 driven by a combination of hydrologic and geomorphic factors (Hupp and Osterkamp, 1996; 472 Hughes, 1997; Corenblit et al., 2007). Accordingly, altered hydrology and morphology within 
473 the regulated Sauce Grande explain upstream-downstream differences in the spatial extent of

474 vegetation growth, in the nature of vegetation transitions, and in patterns of vegetation

475 establishment with distance downstream. .

476 Hydrologic factors. Flow regulation caused two major changes in the river hydrology below

477 the dam that have had direct influence on patterns of vegetation establishment. First, and as

478 reported for many regulated rivers in dryland regions (Table 3), the maintenance of base flow

479 levels has encouraged vegetation to establish on the channel bed and banks. Second, the

480 reduction of the magnitude and frequency of floods resulted in a disruption of lateral

481 processes of river-floodplain connectivity (productivity and disturbance) maintaining riparian

482 succession and diversity (Ward and Stanford, 1995; Ward, 1998). Recruitment of riparian

483 pioneers no longer occurs, and woody vegetation establishes within the main channel, near to

484 the water surface. In contrast to other impounded rivers in drylands, where altered flood

485 regimes caused substantial changes in the composition of riparian communities (e.g., invasion

486 of exotic, drought-tolerant species in the Green and Bill Williams rivers; Table 3), the quasi-

487 suppression of floods in this agricultural stream has encouraged farmers to extend their

488 practices to the river channel. At present, the floodplain is no longer 'active' and the riparian

489 zone is much reduced because of the advancement of agricultural lands.

490 Geomorphic factors. Downstream differences in patterns of vegetation establishment clearly

491 reflect (and influence) channel planform stability. Channel migration promotes establishment

492 of riparian pioneers by providing new bare and moist surfaces suitable for vegetation

493 establishment and growth (Hupp and Osterkamp, 1996; Friedman et al., 1998; Tockner et al.,

494 2010). Within the river upstream, this aspect was evidenced by landscape transitions from

495 bare bank surfaces to woodlands (57\%). Downstream from the dam, lateral channel stability

496 prevented formation of new channel surfaces suitable for vegetation establishment, and

497 therefore vegetation development was constrained to the pre-dam channel shape. Immediately 
below the dam, the valley-like channel forms permitted proliferation of willows over riparian

499 surfaces that are no longer subject to flood disturbance. Farther downstream, the channel is

500 narrower and deeper, which makes the area available for vegetation establishment relatively

501 small. Hence, willows develop discontinuously near the water surface where the bank slope

502 decreases and the soil moisture is high. This aspect explains the high percentage of transitions

503 from water surfaces to woodlands (38\%) within the river corridor downstream.

\section{4.1.3. Reduced channel capacity}

505 Most studies on regulated dryland rivers have documented reduced channel capacity owing to

506 channel aggradation, with vegetation invasion and stabilisation of lateral deposits (e.g.,

507 Mangrove Creek and Cudgegon River in Australia, Chubut River in Argentina, Mejerda River

508 in Tunisia, and many others; Table 3). Within the regulated Sauce Grande, where

509 redistribution of sediment no longer occurs and so stable conditions prevail, reduced channel

510 capacity was primarily related to alternating yet localized vegetation encroachment on the

511 channel banks. Vegetation encroachment was apparent over the first 10 river km below the

512 dam, there where the pre-dam channel shape provided suitable surfaces for vegetation

513 establishment. Downstream thereafter, the channel is too narrow to allow vegetation growth,

514 and discontinuous patterns of vegetation establishment prevailed. In channel sections with

515 little vegetation, field survey revealed formation of small terrace edges on channel banks (e.g.,

516 R6, Fig. 10). Although these terraces are too small to be captured by photointerpretation

517 analysis, they suggest that the banks that have been mapped as a basis for measuring width

518 were conceivably pre-dam banks that have been abandoned as a result of narrowing. If these

519 banks were abandoned, then they would not display any changes in width, but the river would

520 have formed a narrower channel within the abandoned banks. This aspect is evidenced by the

521 fact that the river is actively wandering within the channel (Table 1) and hence suggests that it

522 has created a new, narrower channel within the old one. 
524 The present river constitutes a low-energy stream characterized by marked channel stability. The floodplain is reduced or absent for much of the river course, and vegetation encroachment on channel banks leads to localized contraction of the pre-dam channel capacity. As outlined above, marked channel stability responds to extreme flow regulation in a river section where the influence of tributaries is scarce. Yet the dam history registers erratic, albeit significant

529 episodes of reservoir discharge and two episodes of overflow spill that resulted in downstream flooding. The question at this point is why these episodes of relative high flow did not initiate channel adjustments? We have two possible explanations for apparent channel

532 stability during periods of flow release from the dam. First, the river channel in the vicinity of 533 the dam has been strongly altered by humans to facilitate evacuation of reservoir discharges 534 (e.g., artificial channel deepening, meander cutoff, levee building). Humans have done what 535 the river would have done by itself; the difference in this instance is that the sediment 536 recovered was not redistributed downstream but rather deposited into the levees constructed 537 along the river course to prevent overbank flowing. Second, vegetation growth alongside the 538 stream has conceivably increased the channel roughness and the resistance to erosion of bank 539 materials. In dryland rivers, where complexity and irregularity in morphology, hydrology, and 540 riparian vegetation are the norm (Sandercock et al., 2007), biostabilisation of channel banks 541 and maturation of individuals may contribute to increased thresholds for geomorphic activity 542 (Corenblit et al., 2010).

543 In opposition to these assumptions, however, artificial levee building has been reported to 544 increase rates of bank erosion because the unconsolidated sediment was easily eroded once 545 bank-full flows occurred (Leeks et al., 1988). Furthermore, the comprehensive review of 546 Tooth (2000b) on dryland rivers outlined that even channels heavily vegetated with perennial 547 or ephemeral trees, shrubs and grasses are sometimes subject to flood-related changes (p. 
548 83). These aspects raise two important questions. First, even if vegetation did provide an

549 element of resistance to bank erosion, was the maturation of individuals rapid enough to 550 prevent the levees from being eroded? Second, even if channel banks were biostabilised, was

551 vegetation establishment significant enough to increase thresholds of geomorphic activity? As 552 reported by Petts (1980), the potential for change in regulated rivers depends not only on the 553 channel morphology and materials, but also on the frequency and intensity of competent 554 discharges below the dam. In drylands, this aspect is particularly relevant because a 555 'competent discharge' may be an infrequent, large flood unrepresentative of a more common 556 range of floods (Tooth, 2000b). Accordingly, marked channel stability within this highly 557 regulated dryland river may be interpreted within a model of channel adjustment relative to 558 the frequency and intensity of competent floods with time and distance from dam closure 559 (Fig. 11).

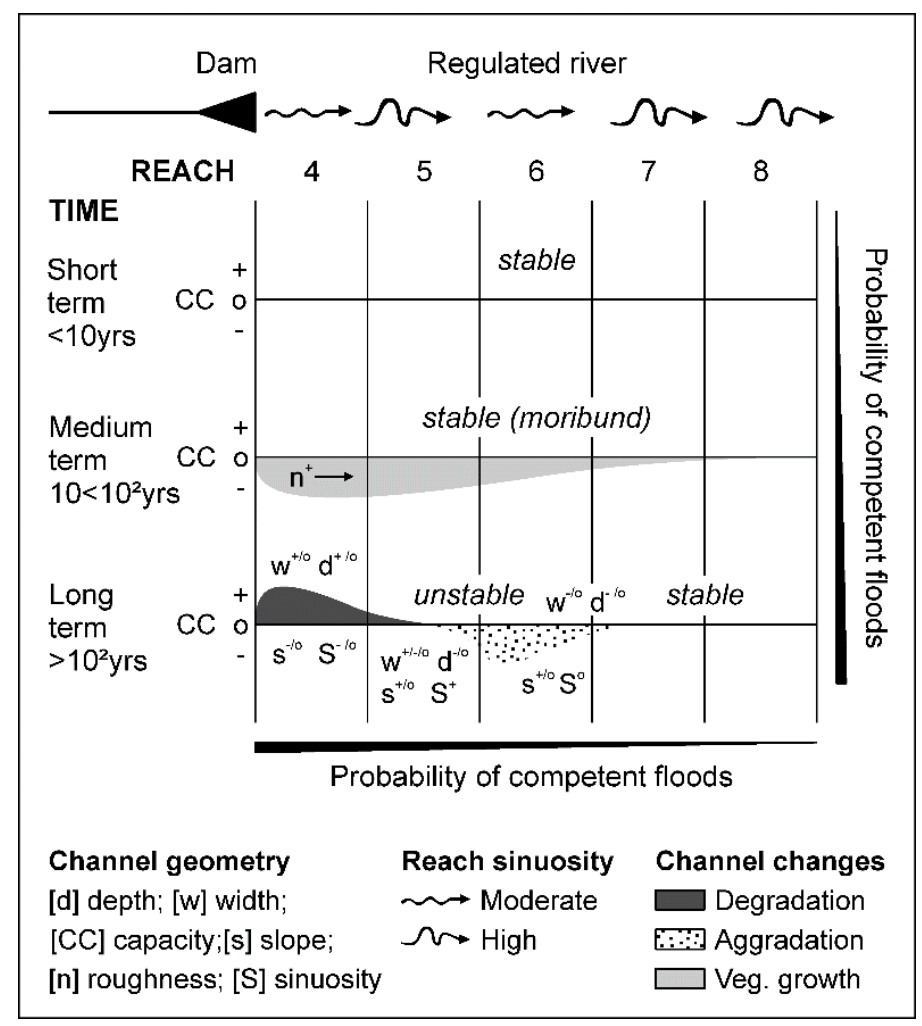

561 Fig. 11. Adjustment of the channel morphology to extreme flow regulation below water562 storage reservoirs in drylands. The model of adjustment (modified from Petts, 1979) considers 
the potential for change relative to the frequency and intensity of competent floods with time and distance from dam closure. The direction of change is indicated by [o] no significant change, $[+]$ increase, and [-] decrease.

566 The unregulated Sauce Grande is in a transient, unstable state (sensu Tooth and Nanson,

567 2000) where complete adjustment of form to process is inhibited until a geomorphically

568 significant flood event occurs. After impoundment by a large surface-area, water-storage

569 reservoir such as Paso de las Piedras, competent floods downstream are unlikely. The channel

570 morphology will not change, and downstream flows will simply accommodate within the

571 existing channel form. As the regulated Sauce Grande receives no major tributaries, the

572 probability of competent floods decreases with distance downstream and so stability will

573 prevail throughout all reaches (Fig. 11).

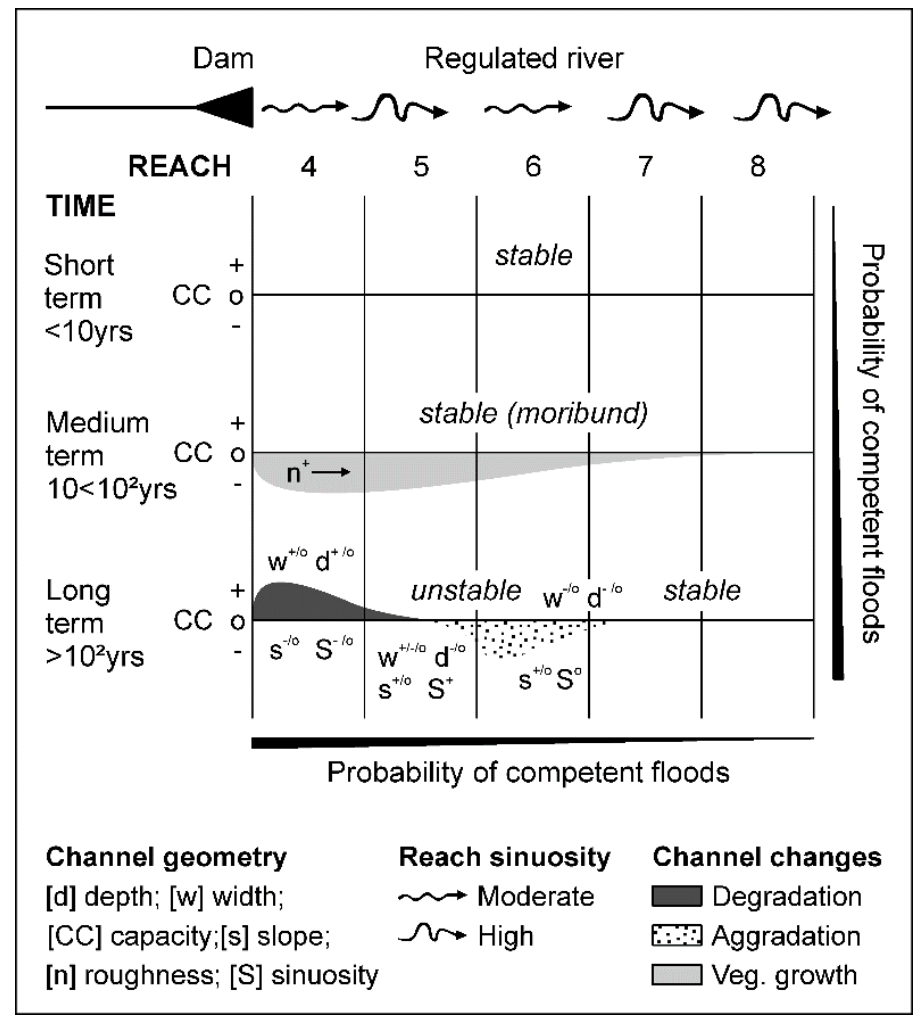

575 Fig. 11. Adjustment of the channel morphology to extreme flow regulation below water-

576 storage reservoirs in drylands. The model of adjustment (modified from Petts, 1979) considers the potential for change relative to the frequency and intensity of competent floods with time 
and distance from dam closure. The direction of change is indicated by [o] no significant change, $[+]$ increase, and [-] decrease.

In addition to enhancing the variability of natural flows (small floods are absorbed within the reservoir, and large floods are either absorbed or markedly reduced), reservoir operations are affected by the effects of ENSO-related cycles of drier- (or wetter-) than-normal climate.

Reservoir discharges during dry spells are unlikely, and if a reservoir discharge is to occur, its magnitude will be most likely below the threshold for geomorphic activity. Thus, the time-lag before channel changes initiate may be considerably longer than in more humid rivers having the propensity to accommodate change, and longer than in dryland rivers regulated by dams having less effects on the frequency and intensity of competent floods downstream. In the absence of competent floods with time, the channel morphology will not change and the river will exhibit stable, moribund conditions. Thorne et al. (1996) defined moribund channels as those that are not strictly alluvial because the observed channel form is the result of processes that operated in the past under conditions of higher energy and/or more abundant sediment supply, so that the geometry and features of the channel are relics of a fluvial environment 593 that no longer exists (p. 471). Accordingly, channel forms will not reflect the regulated flow 594 regime but the effects of the last major flood before closing the dam, and the only remarkable change throughout the reaches will be determined by vegetation invasion and stabilisation of channel banks in sections where the pre-dam channel shape allows vegetation establishment

597 (Fig. 11). Assuming that dam operation procedures will not change in the future, moribund 598 stability will remain indefinitely and if recovery is to occur at all, further human intervention 599 through river restoration is essential (Thorne et al., 1996, p. 471).

600 Yet a geomorphically significant flood is likely to occur with time (Fig. 11). If so, degradation 601 may occur immediately below the dam (reach 4) increasing channel depth and width.

602 Differential erosion by meander migration may produce localised changes of the channel 
603

604

605

606

607

608

609

610

611

612

613

614

615

616

617

618

619

620

621

622

623

624

625

626

627

width in reach 5. Given the low energy of the river section below the dam, the eroded material will be deposited in reach 6 and, within the distal reaches, the channel morphology will not change. Tooth (2000a) reported that in dry, lowland zones with absence of tributaries, channels were stable because of the effects of flow transmission losses and attenuation of flood hydrographs. Although the most obvious spatial comparison contrasts river reaches upstream and downstream from a dam (Braatne et al., 2008), channel stability in this lowgradient lowland river section probably existed prior to dam closure and will remain unless a high-magnitude, low-frequency flood event occurs.

\section{Conclusions}

This paper provided a detailed geomorphic and vegetation assessment within an impounded meandering dryland river where (i) flow regulation is extreme and (ii) the influence of tributaries in the river section below the dam is scarce. In addition to providing new information on the complex geomorphic response of dryland rivers to impoundment, it provides the first geomorphic assessment of the regulated Sauce Grande River. Results from this investigation revealed that aside from human-related adjustments of the channel planform and cross section, the river response to upstream impoundment was characterized by marked channel stability. Because the reservoir impounds nearly the full range of flows and the totality of sediment delivered from the headwaters, redistribution of sediment in the river section below the dam no longer occurs and stable conditions prevail. The present river morphology constitutes a remnant of a fluvial environment created before closing the dam, and the only remarkable change observed since dam closure was reduced channel capacity owing to vegetation encroachment on the channel banks. Vegetation growth alongside this much-reduced stream has been encouraged by maintenance of base flow levels and reduced flood disturbance. Yet vegetation develops only in river sections where the pre-dam channel 
shape is large enough to allow establishment of pioneers. In other words, vegetation

629 establishment is influenced by (and reflects) channel stability.

630 These findings serve as an important platform to enable further research assessing the present

631 geomorphic state of the regulated Sauce Grande River, and they lead to a number of

632 additional questions that require further attention. While the temporal dimension could be

633 assessed robustly, the spatial dimension requires further research efforts to understand the

634 nature of the relationships between form and process within the regulated river as well as the

635 influence of transmission losses (evaporation and infiltration) and attenuation of the flood

636 hydrograph on the downriver channel morphology. One major challenge for further research

637 is the lack of historical flow data along the river course. This makes estimations of pre- and

638 post-dam channel hydraulics very difficult to achieve. Thus, detailed field observations and

639 sediment analyses will be required to identify temporal and spatial variations in the

640 relationship between stream power and critical thresholds for geomorphic effectiveness of

641 regulated flows below the dam. Similarly, this study outlined some interconnections between

642 regulated flow, channel forms, and vegetation dynamics. However, detailed vegetation

643 analyses are required to assess the complex mechanisms by which vegetal successions in this

644 regulated river influence (and are influenced by) channel morphology.

645

\section{Acknowledgements}

647 The authors thank the ADA Authority, Marta Crisafulli, and the rest of the ADA staff for

648 permitting access to the Paso de las Piedras Dam complex, for providing assistance with

649 equipment installation and survey, and for providing flow data. The authors also thank Paul

650 Ledger and Johannes Steiger for providing assistance and constructive comments to the

651 manuscript. Funding was provided to Ana Casado by the Consejo Nacional de

652 Investigaciones Científicas y Técnicas (CONICET) post-graduate scholarship. This paper 
653 would not have the present form without the valuable comments and suggestions of Paul

654 Grams, Carlos Zavala, and four anonymous reviewers.

655

\section{References}

657 Andrés, F., Bambill, E., Bandoni, A., Campaña, H., Carrica, J., Cifuentes, O., Parodi, E.R., 658 Piccolo, M.C., Poggio, J., Varela, H., Schefer, J.C., 2009. Informe técnico sobre aspectos 659 relevantes de la problemática del agua en la región de Bahía Blanca, Technical report of the 660 Universidad Tecnológica Nacional - Universidad Nacional del Sur, Bahía Blanca.

661 Andrews, E.D., 1986. Downstream effects of Flaming Gorge Reservoir on the Green River, 662 Colorado and Utah. Geological Society of America Bulletin, 97, 1012-1028.

663 Benn, P.C., Erskine, W.D., 1994. Complex channel response to flow regulation: Cudgegong 664 River below Windamere Dam, Australia. Applied Geography, 14, 153-168.

665 Blanchon, D., Bravard, J.-P., 2007. La stabilité des formes fluviales de l'Orange, entre 666 variabilité naturelle et impacts des grands barrages (secteur Boegoeberg-Augrabies, Afrique du 667 Sud). Géographie Physique et Quaternaire, 61, 21-37.

668 Bohn, V.Y., Piccolo, M.C., Perillo, G.M.E., 2011. Análisis de los periodos secos y húmedos en 669 el sudoeste de la provincia de Buenos Aires (Argentina). Revista de Climatología, 11, 31-43.

670 Borromei, A.M., 1991. Geología y palinología de los depósitos cuaternarios en el valle del río 671 Sauce Grande. Doctoral thesis, Universidad Nacional del Sur, Bahía Blanca, 199 pp.

672 Braatne, J.H., Rood, S.B., Goater, L.A., Blair, C.L., 2008. Analyzing the impacts of dams on 673 riparian ecosystems: a review of research strategies and their relevance to the Snake River 674 through Hells Canyon. Environmental Assessment, 41, 267-281.

675 Brandt, S.A., 2000. Classification of geomorphological effects downstream of dams. Catena, $67640,375-401$.

677 Bull, L.J., Kirkby, M.J., 2002. Dryland river characteristics and concepts. In: Bull, L.J., Kirkby, 
678 M.J. (Eds.), Dryland rivers: hydrology and geomorphology of semi-arid channels. John Wiley 679 \& Sons, Chichester, pp. 3-16.

680 Bunn, S.E., Thoms, M.C., Hamilton, S.K., Capon, S.J., 2006. Flow variability in dryland rivers: 681 boom, bust and the bits between. River Research and Applications, 22, 179-186.

682 Campo, A.M., Ramos, M.B., Zapperi, P., 2009. Análisis de las variaciones anuales de 683 precipitación en el Suroeste bonaerense, Argentina. Proceedings of the XII Encuentro de 684 Geógrafos de América Latina, Montevideo, Uruguay.

685 Casado, A., Gentili, J., Campo, A.M., Peiry, J.-L., 2010. Evaluación de la calidad de modelos 686 digitales de elevación derivados de curvas de nivel para aplicaciones hidrológicas. In: Carbone, 687 M.E., Melo, W.D., Angeles, G.R. (Eds.), Tecnologías de la Información Geográfica del sur 688 argentino. UNS, Bahia Blanca, pp. 102-116.

689 Chien, N., 1985. Changes in river regime after the construction of upstream reservoirs. Earth 690 Surface Processes and Landforms, 10, 143-159.

691 Corenblit, D., Tabacchi, E., Steiger, J., Gurnell, A.M., 2007. Reciprocal interactions and 692 adjustments between fluvial landforms and vegetation dynamics in river corridors: A review of 693 complementary approaches. Earth-Science Reviews, 84, 56-86.

694 Corenblit, D., Steiger, J., Tabacchi, E., 2010. Biogeomorphologic succession dynamics in a 695 Mediterranean river system. Ecography, 33, 1136-1148.

696 Darby, S.E., Thorne, C.R., 2000. A river runs through it: morphological and landowner 697 sensitivities along the upper Missouri River, Montana, USA. Transactions of the Institute of 698 British Geographers, 25, 91-107.

699 Davies, B.R., Thoms, M.C., Walker, K.F., O'Reeffe, J.H., Gore, J.A., 1994. Dryland rivers: 700 their ecology, management and conservation. In: Calow, P., Petts, G.E. (Eds.), The Rivers 701 Handbook: Hydrological and Ecological Principles. Vol. 2. Blackwell Science, Oxford, pp. 702 484-511. 
Downward, S.R., Gurnell, A.M., Brookes, A., 1994. A methodology for quantifying river

704 channel planform change using GIS. Variability in Stream Erosion and Sediment Transport,

705 Proceedings of the Canberra Symposium. IAHS Publ. no. 224, Canberra, pp. 449-456.

706 Everitt, B.L., 1993. Channel responses to declining flow on the Rio Grande between Ft.

707 Quitman and Presidio, Texas. Geomorphology, 6, 225-242.

708 Friedman, J.M., Osterkamp, W.R., Scott, M.L., Auble, G.T., 1998. Downstream effects of dams 709 on channel geometry and bottomland vegetation: regional patterns in the Great Plains. 710 Wetlands, 18, 619-633.

711 Gordon, E., Meentemeyer, R.K., 2006. Effects of dam operation and land use on stream channel 712 morphology and riparian vegetation. Geomorphology, 82, 412-429.

713 Graf, W.L., 1988. Fluvial processes in dryland rivers. The Blackburn Press, Caldwell.

714 Grams, P.E., Schmidt, J.C., 2002. Streamflow regulation and multi-level flood plain formation: 715 channel narrowing on the aggrading Green River in the eastern Uinta Mountains, Colorado and 716 Utah. Geomorphology, 44, 337-360.

717 Grams, P.E., Schmidt, J.C., Topping, D.J., 2007. The rate and pattern of bed incision and bank 718 adjustment on the Colorado River in Glen Canyon downstream from Glen Canyon Dam, 19567192000 Geological Society of America Bulletin, 119, 556-575.

720 Grimalt, F., Grimalt, M.E., 2005. La evolución del río San Juan aguas abajo del Azud I. de la 721 Roza, luego de la puesta en marcha de la presa de Ullum al año 2004. Proceedings of the XX 722 Congreso Nacional del Agua, Mendoza.

723 Howard, A., Dolan, R., 1981. Geomorphology of the Colorado River in the Grand Canyon. The 724 Journal of Geology, 89, 269-298.

725 Hughes, F.M.R., 1997. Floodplain biogeomorphology. Progress in Physical Geography, 21, $726 \quad 501-529$.

727 Hupp, C.R., Osterkamp, W.R., 1996. Riparian vegetation and fluvial geomorphic processes. 
Geomorphology, 14, 277-295.

729 Kaless, G., Matamala, F., Monteros, B., Greco, W., 2008. Cambios hidrológicos y morfológicos en el río Chubut aguas debajo de la presa Florentino Ameghino. Proceedings of the V Congreso Argentino de Presas y Aprovechamientos Hidroeléctricos, San Miguel de Tucumán.

Leeks, G.J., Lewin, J., Newson, M.D., 1988. Channel change, fluvial geomorphology and river engineering: the case of the Aton Trannon, mid-Wales. Earth Surface Processes and Landforms, $13,207-223$.

Lefort, P., Chapuis, M., 2012. Incidence des aménagements hydro-électriques sur la morphologie des tronçons court-circuités de la Durance. La Houille Blanche, 2, 42-48.

Ma, Y., Huang, H., Nanson, G.C., Li, Y., Yao, W., 2012. Channel adjustments in response to the operation of large dams: the upper reach of the lower Yellow River. Geomorphology, 147, $35-48$.

Magdaleno, F., Fernandez, A., 2010. Hydromorphological alteration of a large Mediterranean river: relative role of high and low flows on the evolution of riparian forests and channel morphology. River Research and Applications.

Makhlouf, Z., Michel, C., 1994. A two-parameter monthly water balance model for French 744 watersheds. Journal of Hydrology, 162, 299-318.

745 Merritt, D.M., Cooper, D.J., 2000. Riparian vegetation and channel change in response to river 746 regulation: a comparative study of regulated and unregulated streams in the Green River Basin, 747 USA. Regulated Rivers: Research \& Management, 16, 543-564.

748 Naiman, R.J., Décamps, H., 1997. The ecology of interfaces: riparian zones. Annual Review of 749 Ecology and Systematics, 28, 621-658.

750 Nanson, G.C., Tooth, S., Knighton, A.D., 2002. A global perspective on dryland rivers: 751 perceptions, misconceptions and disctinctions. In: Bull, L.J., Kirkby, M.J. (Eds.), Dryland 752 rivers: hydrology and geomorphology of semi-arid channels. John Wiley \& Sons, Chichester, 
pp. 17-54.

754 Paoloni, J.D., Tjuchneider, O.C., Luque, J.A., 1972. Caracterización hidrológica de la cuenca 755 del río Sauce Grande en primera fase. Investigaciones Agropecuarias, Serie 3: Clima y Suelo, $7569,127-146$.

757 Penalba, O.C., Vargas, W.M., 2004. Interdecadal and interannual variations of annual and 758 extreme precipitation over central-northeastern Argentina. International Journal of 759 Climatology, 24, 1565-1580.

760 Petts, G.E., 1979. Complex response of river channel morphology subsequent to reservoir 761 construction. Progress in Physical Geography, 3, 529-632.

762 Petts, G.E., 1980. Long-term consequences of upstream impoundment. Environmental 763 Conservation, 7, 325-332.

764 Petts, G.E., 1984. Impounded Rivers. John Wiley \& Sons, Chichester.

765 Petts, G.E., Gurnell, A.M., 2005. Dams and geomorphology: Research progress and future 766 directions. Geomorphology, 71, 22-47.

767 Poff, N.L., Ward, J.V., 1989. Implications of streamflow variability and predictability for lotic 768 community structure: a regional analysis for streamflow patterns. Canadian Journal of Fisheries 769 and Aquatic Sciences, 46, 1805-1817.

770 Quattrocchio, M.E., Deschamps, C.M., Zavala, C., Borromei, A.M., Grill, S., Guerstein, R., 771 1993. Cuaternario del Sur de la provincia de Buenos Aires: Estratigrafía e inferencias 772 paleoambientales. In: Iriondo, M. (Ed.), El Holoceno en Argentina. CADINQUA, pp. II:22-34. 773 Quattrocchio, M.E., Borromei, A.M., Deschamps, C.M., Grill, S., Zavala, C., 2008. Landscape 774 evolution and climate changes in the Late Pleistocene-Holocene, southern Pampa (Argentina): 775 Evidence from palynology, mammals and sedimentology. Quaternary International, 181, 123776 138.

777 Rabassa, J., 1982. Variación regional y significado geomorfológico de la densidad de drenaje 
en la cuenca del río Sauce Grande, provincia de Buenos Aires. Revista de la Asociación

779 Geológica Argentina, 37, 268-284.

780 Richard, G., Julien, P.Y., 2003. Dam impacts on and restoration of an alluvial river -Rio Grande,

781 New Mexico. International Journal of Sediment Research, 18, 89-96.

782 Sandercock, P.J., Hooke, J.M., Mant, J.M., 2007. Vegetation in dryland river channels and its

783 interaction with fluvial processes. Progress in Physical Geography, 31, 107-129.

784 Schefer, J.C., 2004. Los recursos hídricos y el abastecimiento de agua. CEPADE, Bahía Blanca.

785 Schmandt, J., North, G.R., Ward, G.H., 2013. How sustainable are engineered rivers in arid

786 lands? Journal of Sustainable Development of Energy, Water and Environment Systems, 1, 78-

78793.

788 Schmidt, J.C., Everitt, B.L., 2000. Hydrology and geomorphology of the Rio Grande/Rio Bravo

789 between Fort Quitman and Amistad Reservoir and implications for river restoration.

790 Proceedings of the Rio Grande/Rio Bravo Binational Symposium, Juarez, Mexico.

791 Scian, B., 2000. Episodios ENSO y su relación con las anomalías de precipitación en la pradera

792 pampeana. Geoacta, 25, 23-40.

793 Shafroth, P.B., Stromberg, J.C., Patten, D.T., 2002. Riparian vegetation response to altered

794 disturbance and stress regimes. Ecological Applications, 12, 107-123.

795 Sherrard, J.J., Erskine, W.D., 1991. Complex response of a sand-bed stream to upstream

796 impoundment. Regulated Rivers: Research \& Management, 6, 53-70.

797 Shields, F.D., Simon, A., Steffen, L.J., 2000. Reservoir effects on downstream river channel 798 migration. Environmental Conservation, 27, 54-66.

799 Simon, A., Thomas, R.E., Curini, A., Shields, D., 2002. Case study: channel stability of the 800 Missouri River, eastern Montana. Journal of Hydraulic Engineering, 128, 880-890.

801 Stevens, L.E., Schmidt, J.C., Ayers, T.J., Brown, B.T., 1995. Flow Regulation,

802 Geomorphology, and Colorado River Marsh Development in the Grand Canyon, Arizona. 
Ecological Applications, 5, 1025-1039.

804 Stromberg, J.C., Shafroth, P.B., Hazelton, A.F., 2012. Legacies of flood reduction on a dryland 805 river. River Research and Applications, 28, 143-159.

806 Thoms, M.C., Walker, K.F., 1993. Channel changes associated with two adjacent weirs on a 807 regulated lowland alluvial river. River Research and Applications, 8, 271-284.

808 Thorne, C.R., 1993. Guidelines for the use of stream reconnaissance record sheets in the field. 809 U.S. Army Corps of Engineers, Washington.

810 Thorne, C.R., Allen, R.G., Simon, A., 1996. Geomorphological river channel reconnaissance 811 for river analysis, engineering and management. Transactions of the Institute of British 812 Geographers, 21, 469-483.

813 Tilleard, J.W., Erskine, W.D., Rutherfurd, I.D., 1994. Impacts of River Murray flow regulation 814 on downstream channel morphology. Proceedings of the Water Down Under '94, Adelaide, 815 Australia, 409-415.

816 Tockner, K., Lorang, M.S., Stanford, J.A., 2010. River flood plains are model ecosystems to 817 test general hydrogeomorphic and ecological concepts. River Research and Applications, 26, $818 \quad 76-86$.

819 Tooth, S., 2000a. Downstream changes in dryland river channels: the Northern Plains of arid 820 central Australia. Geomorphology, 34, 33-54.

821 Tooth, S., 2000b. Process, form and change in dryland rivers: a review of recent research. Earth 822 Science Reviews, 51, 67-107.

823 Tooth, S., 2013. Dryland fluvial environments: assessing distinctiveness and diversity from a 824 global perspective. In: Shroder, J.F. (Ed.), Treatise on Geomorphology. Academic press, San 825 Diego, pp. 612-644.

826 Tooth, S., Nanson, G.C., 2000. Equilibrium and nonequilibrium conditions in dryland rivers.

827 Physical Geography, 21, 183-211. 
UNEM, 2011. Global Drylands: a UN system-wide response. United Nations Environment

Management Group.

830 Walker, K.F., Sheldon, F., Puckridge, J.T., 1995. A perspective on dryland river ecosystems.

831 Regulated Rivers: Research \& Management, 11, 85-104.

832 Wang, Z., Hu, C., 2004. Interaction between fluvial systems and large scale hydro-projetcs.

833 Proceedings of the Ninth International Symposium on River Sedimentation, Yichang, China,

$834 \quad 46-64$.

835 Wang, Z., Wu, B., Wang, G., 2007. Fluvial processes and morphological response in the Yellow

836 and Weihe Rivers to closure and operation of Sanmenxia Dam. Geomorphology, 91, 65-79.

837 Ward, J.V., 1998. Riverine landscapes: biodiversity patterns, disturbance regimes, and aquatic

838 conservation. Biological Conservation, 83, 269-278.

839 Ward, J.V., Stanford, J.A., 1995. Ecological connectivity in alluvial river ecosystems and its

840 disruption by flow regulation. Regulated Rivers: Research \& Management, 11, 105-119.

841 Wellmeyer, J.L., Slattery, M.C., Phillips, J.D., 2005. Quantifying downstream impacts of 842 impoundment on flow regime and channel planform, lower Trinity River, Texas.

843 Geomorphology, 69, 1-13.

844 Williams, G.P., Wolman, M.G., 1984. Downstream effects of dams on alluvial rivers, US 845 Government Printing Office, Washington.

846 Young, W.J., Kingsford, R.T., 2006. Flow variability in large unregulated dryland rivers. In:

847 Kingsford, R.T. (Ed.), Ecology of desert rivers. Cambridge University Press, Cambridge, pp. $848 \quad 11-46$.

849 Zahar, Y., Ghorbel, A., Albergel, J., 2008. Impacts of large dams on downstream flow 850 conditions of rivers: Aggradation and reduction of the Medjerda channel capacity downstream 851 of the Sidi Salem dam (Tunisia). Journal of Hydrology, 351, 318-330.

852 Zavala, C., Quattrocchio, M.E., 2001. Estratigrafía y evolución geológica del río Sauce Grande 
853 (Cuaternario), provincia de Buenos Aires, Argentina. Revista de la Asociación Geológica 854 Argentina, 56, 25-37. 